Article

\title{
Corporate Environmental Responsibility through the Prism of Strategic Management
}

\author{
Alla Kasych ${ }^{1, *}$, Petr Suler ${ }^{2}$ and Zuzana Rowland ${ }^{2}$ \\ 1 Department of Management and Public Administration, Kyiv National University of Technologies and Design, \\ 2 Nemirovich-Danchenko Street, 01011 Kyiv, Ukraine \\ 2 School of Expertness and Valuation, Institute of Technology and Business, Okruzni 517/10, \\ 37001 Ceske Budejovice, Czech Republic; petr.suler@cez.cz (P.S.); rowland@mail.vstecb.cz (Z.R.) \\ * Correspondence: kasich.alla@gmail.com; Tel.: +38-067-532-8587
}

Received: 30 September 2020; Accepted: 11 November 2020; Published: 17 November 2020

check for updates

\begin{abstract}
This contribution considers the theoretical, methodological, and analytical aspects of implementing a strategic approach to the management of corporate environmental responsibility in practice. The economic and normative approach to understanding the essence of corporate environmental responsibility is revealed; the key factors are systematized. Based on the generalization of theoretical and methodological provisions for corporate environmental responsibility, the authors formulated a concept for the strategic management thereof. An approach to understanding the content and forms of environmental responsibility at different stages of a company's lifecycle is formulated. The main indicators that enable the analysis of corporate environmental responsibility from the point of view of the chain "inputs-processes-outputs" are systematized. Analytical studies of corporate environmental responsibility are conducted on the basis of information concerning automotive companies, in particular in terms of the following main areas: the study of global trends, monitoring of environmental goals and their reflection in development strategy, comprehensive analysis of environmental responsibility, the study of the balance of environmental and economic indicators. To achieve the aforementioned, the following were used: quantitative and qualitative methods, analytical and comparative methods of processing, analysis and synthesis of statistical information, economic and mathematical modelling, etc. The mechanism of transforming global environmental challenges into environmental responsibility management in practice is substantiated. An organizational mechanism is put forward for developing an environmental responsibility management system based on a strategic approach focused on implementation in practice. The key tools for implementing theoretical and methodological provisions in management practice are also identified.
\end{abstract}

Keywords: corporate environmental responsibility; environmental management systems; ecological goals; analysis; sustainability

\section{Introduction}

The long-term strategic-oriented vision of humanity's future is reflected in the concept of sustainable development, formulated as the agenda of society for the 21st century, which determines the need to manage a systemic whole-the chain "man-biosphere-economy". As early as 1798, the English economist and priest Thomas Malthus ("An Essay on the Principle of Population") [1] formulated the problem of human impact on the environment, which remains unresolved and exacerbated under today's circumstances. For example, from 1960 to 2000, the world's population doubled from 3 trillion to 6 trillion, with the value of GDP during this period increasing 24.6 times. From 2000 to 2019, the dynamics slowed down, but the world's population still increased by $25.5 \%$ to 
7.6 trillion, with total GDP increasing 2.6 times [2]. That is, the increase in the world's population causes an n-fold increase in total output, and therefore a significant increase in the consumption of natural resources, including materials, water, energy, and more. Analysts estimate that $50 \%$ more natural resources are extracted and used today than 50 years ago; about 60 billion tonnes of raw materials per year [3]. According to UN forecasts, by 2050, the world's population will increase from 7.6 to 9.8 billion people [4]; the number of middle-class consumers will increase to 5.2 billion people by 2030 [5], respectively, and the demand for resources will increase exponentially. By 2030, the world population's need for food will increase by at least $50 \%$, for energy by $45 \%$, and for water by $30 \%$. Given the current trends in the consumption of natural resources, their production by 2030 may increase to 100 billion tonnes [3], which means an even greater burden being placed on the environment and the accumulation of environmental problems.

The implementation of the concept of sustainable development will only be possible through the large-scale consolidation of the efforts of societies, governments, and industrial companies. According to [6], environmental quality and economic progress can go hand in hand at the macro-level. However, at the micro-level, whereas economic goals and social responsibility standards are being achieved, environmental responsibility remains a lower priority for companies. At the same time, companies are active participants in solving society's environmental problems, in particular through the introduction of modern technologies that reduce emissions, thereby reducing the burden on the environment.

The whole set of environmental measures implemented by a company fits into the concept of environmental responsibility, which is a complex management task in practice. In some cases, economic obstacles can exceed the social incentives. The ecological responsibility of a company lies, first of all, in the processes and technologies used for production. However, in these terms, achieving the environmental performance of industry leaders is a complex long-term process because the investment in environmentally friendly technologies is large, even for large powerful companies. The economic barriers become insurmountable, with companies choosing to either indefinitely delay the implementation of the principles of environmental management or ignoring them under all possible conditions.

Given the systemic nature of these problems, as well as the real need to increase the level of environmental responsibility of all companies, it has been proposed to apply a strategic approach, one which provides choices in terms of goals, product selection, competitive positions in the market, and seeking diversity, etc. [7]. Within this context, it is necessary to give specific arguments for the importance of studying the processes of increasing environmental responsibility from the strategic point of view.

Firstly, the environmental situation is critical. Managing this at the micro-level therefore requires effective and far-sighted solutions, which by their very nature are strategic decisions in terms of their scale, complexity, and impact on the success or failure of a company [8].

Secondly, the strategic approach determines the need to form and introduce long-term guidelines in the field of interaction with the external environment and to combine them with the economic and social aspects of companies.

Thirdly, environmental goals are increasingly reflected in corporate strategies and should therefore be a priority for companies that are focused on long-term competitiveness.

Fourthly, increasing a company's level of environmental responsibility requires significant resources for implementation. The environmental strategy should therefore be considered part of the company's overall system of development strategies and based on the development of its economic potential.

International agreements on emissions reductions, the implementation of ISO 14001 [9], and the demands of society are just some of the levers that can be used for implementing the principles of environmental responsibility in practice in a growing number of companies. Of even greater importance is management practice and the results achieved by industry leaders, both of which 
provide a benchmark for environmental responsibility and determine long-term trends. For followers, especially in developing countries, it is important to understand the management technologies used by industry leaders because they focus on the environmental standards of the developed world.

Environmental responsibility is therefore an integral characteristic of a modern competitive company, which requires strategically oriented management on a constant scientific basis.

This contribution aims to determine methodological provisions for a strategic approach to environmental responsibility management based on a synthesis of existing theory and the study of the environmental responsibility management systems of real companies in a particular industry.

Based on the goal, it is necessary: to generalize the existing scientific approaches to environmental responsibility management within companies, to offer a conceptual approach to the development of an environmental responsibility management system, to improve the methodological provisions for monitoring the environmental responsibility of companies, to study the experience of companies that actively adhere to the principles of environmental responsibility, and to substantiate the content of management measures to increase the level of environmental responsibility. This list forms the basis for logic and structure of the study presented.

\section{Literature Review and Hypothesis Development}

\subsection{The Essence of Corporate Environmental Responsibility and Its Role in the Development of Environmental Management Systems}

Environmental responsibility is a complex socio-economic and environmental-legal institution that exists in the forms of legal and economic responsibility, the nature of which is revealed in [10].

From a legal point of view, the responsibility lies primarily in the obligation to pay taxes. The principle of environmental responsibility, from this position, is as follows-responsibility for environmental damage is transferred to those who cause harm.

From an economic point of view, environmental responsibility is reflected in the costs incurred in fulfilling a company's obligations to the environment. More specifically, at the corporate level, environmental responsibility means, according to the definition in [11], the obligation of a company to cover the environmental consequences of the company: products and equipment used, reduce waste and emissions, maximize the efficiency and productivity of resources, and minimize activities that could negatively affect a country's resources for future generations.

However, this vision of the subject is quite limited, as increasing the level of corporate environmental responsibility contributes to secondary effects in the socio-economic environment of a company: the company's products increase the level of consumer demand for products from other companies, the establishment of corporate educational systems and raising the level of education of employees contributes to the spread of the practice of environmentally responsible behavior in society, leading corporations take responsibility for improving the environmental situation in their areas of activity, etc.

The issue of ensuring environmental responsibility is the subject of environmental management research. System studies of the processes of formation and monitoring of environmental management systems are presented in works [10-15].

"An environmental management system is a tool used by a company to identify a measure and manage the effects of its activities on the environment" [16].

The introduction of an environmental management system aims to produce environmentally friendly products and prevent environmental pollution [17].

According to [14], among the key secondary effects of implementing an environmental management system are market share, employee motivation, customer loyalty, efficiency, and profitability.

The key conditions for the successful implementation of environmental management systems are considered in [18]. In [17], the researchers describe the elements of the management system formed, based on environmental management system standards, and conclude that only a systematic approach to environmental management can achieve the desired results in terms of overall performance indicators. 
According to ISO 14001 standards, Environmental Management Systems (EMS) include five main elements: environmental policy, environmental planning, environmental implementation and operations, checking and corrective actions, and management review [9].

For the EMS to work, effective subsystems must be created: environmental policy implemented by senior management, planning process aimed at incorporating environmental issues in the management system, organizational structure that ensures responsibility and accountability, implementation and operational control systems, measurement and audit systems.

From the point of view of the process, the authors [14] consider the EMS to involve a constant cycle of planning, implementation, revaluation, and improvement phases related to organizational processes, whereby the criterion of efficacy is the constant improvement of environmental performance.

In summarizing the approaches to the formation and functioning of environmental management systems, as well as taking into account the complexity of the requirements for companies in the field of environmental management, the following should also be noted:

Firstly, the issue of a company's interaction with the environment should be raised from the level of efficiency to the level of responsibility towards stakeholders and society.

Secondly, the process of corporate environmental responsibility management should be an integral part of the general management system of a company and its mechanisms and tools.

Thirdly, the effects of increasing the level of corporate environmental responsibility should not only be considered from the standpoint of the company itself, but also from the standpoint of providing a real solution to global environmental problems.

Existing scientific provisions, which form the theoretical basis for improving the systems of strategic management regarding interaction with the environment, especially in terms of corporate responsibility, should be presented in a structured form that covers several interrelated areas.

\subsection{Research into the Effects of Key Factors on the Formation of Ecological Management Systems}

Even though environmental responsibility, in essence, is the embodiment of the self-orientation and self-determination of a company, it is formed under the influence of both internal and external factors.

In [19], consideration is given to the main factors behind corporate environmental responsibility and concludes that state legislation is the number one driver.

In [20], the authors reveal the nature of external and internal factors, and the main barriers and advantages of implementing a system of corporate environmental responsibility. Among the key factors, the authors highlight the regulatory framework, market forces, stakeholder pressure, and self-regulation.

Most scientists indicate such key factors behind corporate environmental responsibility: regulatory forces, market forces, self-regulation, and stakeholder influence [21]. A slightly different approach was proposed when the authors considered such motives as regulation, public concern, competitive advantage, and the commitment of senior management.

The general increase in environmental responsibility among companies is due to many factors, which can be distinguished by the nature of the action: external factors of a coercive nature, external factors of a motivational nature, and internal factors, as shown in Table 1.

Table 1. The main factors for increasing corporate environmental responsibility.

\begin{tabular}{ccc}
\hline $\begin{array}{c}\text { External Factors of a Coercive } \\
\text { Nature }\end{array}$ & $\begin{array}{c}\text { External Factors of a } \\
\text { Motivational Nature }\end{array}$ & Internal Factors \\
\hline $\begin{array}{c}\text { Unification of regulatory norms as } \\
\text { a result of globalization. }\end{array}$ & $\begin{array}{c}\text { Competition in the business } \\
\text { environment. }\end{array}$ & $\begin{array}{c}\text { Recognition by the management of } \\
\text { the importance to the company of } \\
\text { increasing the level of } \\
\text { environmental responsibility. }\end{array}$ \\
\hline Regulations in different countries. & $\begin{array}{c}\text { Development of public } \\
\text { consciousness. }\end{array}$ & $\begin{array}{c}\text { Technical and technological } \\
\text { development of the company. }\end{array}$ \\
\hline
\end{tabular}


The concept of regulating environmental responsibility aims to create the conditions and provide incentives that will encourage the better behavior of companies towards the environment. As competition intensifies and environmental responsibility is elevated to being an important factor, so too does the importance of having environmentally friendly products and the greening of production processes. The influence of consumers manifests itself in the unification of the requirements regarding the environmental performance of products; competitors determine the industry's technological trends and therefore the required level of investment for the introduction of eco-technologies and closed-loop production processes. The creation of competitive advantage based on environmental responsibility is a long-term strategic task for a company because it requires significant investment. However, large powerful companies are increasingly pursuing environmental goals, given the growing social and humanitarian significance thereof.

Based on the understanding of the complexity of the dependence and impact of corporate environmental responsibility on the environment, we can formulate the following hypothesis.

Hypothesis 1 (H1). The environmental goals of leading companies are aligned with social development goals and vice versa, as a result of which the implementation of corporate environmental goals helps increase the level of environmental responsibility of society as a whole.

Public recognition of the general responsibility of companies for the global environmental situation manifests itself in the form of pressure placed by various social groups and nongovernmental organizations or companies to produce environmentally friendly products, introduce environmentally friendly technologies, and to implement a common policy on environmental responsibility.

A key internal factor that affects a company's environmentally responsible behavior is the recognition by senior management of the importance of implementing an environmental strategy as part of modern corporate governance. According to their qualifications and understanding of global trends, the implementation of environmental management depends on top managers who determine a company's strategic priorities.

An internal factor that plays a role in increasing environmental responsibility in companies is investment in their technical and technological development. In one way or another, investments in fixed assets and/or R\&D contribute to increasing the level of environmental responsibility of a company-the replacement of obsolete fixed assets by new companies automatically achieves better environmental performance, and investment in R\&D is primarily aimed at improving products, in particular in terms of their consumer characteristics and the need to improve environmental performance.

Ensuring that a company has an appropriate level of investment activity and proper financing for innovations enables companies to redirect resources to ensure environmental responsibility. Based on the understanding of the laws of investment and innovation processes, as well as the importance of increasing the level of environmental responsibility, a hypothesis was formulated to reflect these relationships.

Hypothesis 2 (H2). The level of ecological responsibility of companies with high investment and innovation activities is higher.

\subsection{Formation and Improvement of Environmental Management Systems and the Impact on the Efficiency of Companies}

The formation and improvement of environmental management systems largely depends on the efficiency of companies. Efficiency is a key issue when it comes to increasing a company's level of environmental responsibility because the process requires significant investment and outlays.

The impact of a company's environmental management system on efficiency and profitability is considered in [14]. Based on best practices, EMS integration can reduce various operating costs in the future, which adds value to the organization through future benefits that increase business 
efficiency. The key characteristics of environmental management systems are comprehensively studied in this contribution and are presented in the following list: accuracy, systematization, realism, complexity, up to each level of decision making, full registration, integration, flexibility/dynamism, continuous improvement.

A major obstacle to implementing an environmental management system is the high cost of environmental measures and their negative impact on financial performance. On the other hand, it is equally important to improve a company's reputation, which may outweigh such factors [22], and which is fully consistent with the company's long-term strategic goals.

Eco-control plays an important role in the environmental management system. This involves the use of financial and strategic methods to check the impact of the company on the environment. These problems are revealed in [23].

Understanding that the results achieved by a company can limit the process of implementing the principles of environmental management enabled us to formulate the following hypothesis.

Hypothesis 3 (H3). The performance of companies with a higher level of environmental responsibility is higher.

The dynamics of economic indicators determine the dynamics of environmental responsibility indicators, whereby the ability of a company to increase its level of environmental responsibility depends on the lifecycle stage it finds itself in.

\subsection{Research into the Processes for the Formation and Realization of Environmental Strategy}

In practice, the result of implementing a strategic approach to environmental responsibility management is an environmental strategy.

The experience of developing environmental strategies and implementing a company's environmental policy was studied in [24], whereby the authors concluded that there is a weak link between environmental strategies and efficiency.

In terms of the environment, the demand for effective business practices is growing as public awareness of environmental issues increases. This, in part, is due to pressure from legislators, environmental organizations, and financial institutions, but more and more due to companies themselves developing environmental strategies in light of their interactions with the environment they operate in $[17,25]$.

As highlighted in [26], the traditional approach to the meaningful formation of environmental strategy is to use the concept of the 4Ps (product, price, place, promotion).

On the basis of the aforementioned, it is necessary to theoretically and methodologically justify the information that supports the system for the strategic management of corporate environmental responsibility.

\section{Methodology}

\subsection{The Concept of Strategic Management of Corporate Environmental Responsibility}

The environmental responsibility of companies under current conditions, whereby environmental problems are becoming significantly aggravated or are acquiring a global character, is important for social development reasons and requires systematic strategically oriented management. Many of the world's leading corporations have incorporated environmental responsibility within their management processes at all levels and within all functional areas. For many others, the task of greening their activities has been postponed indefinitely. Since the general trend in company development guidelines is clear and leans towards sustainability and responsibility, especially with regards to the interaction with the environment, it is necessary to take a closer look at the formation of a holistic vision of the formation or improvement of environmental responsibility management systems through the prism of a strategic approach. 
The substantiation of effective management tools to increase the level of environmental responsibility of a company should be based on a new understanding of the concept, within which it is necessary to clarify the substantive characteristics of the subject and form theoretical and methodological provisions, which should then form the basis for implementing the principles of sustainable development and interactions with the environment.

It is for this reason that the words of Joshi ring true, namely "corporate environmental responsibility is a relatively new concept which includes different ideas, actions, strategies and ideologies" [10].

Based on this vision, and based on the understanding of the growing importance of corporate environmental responsibility in terms of effects, as well as taking into account the complexity of the processes and the need to introduce a new vision, it is appropriate to outline the conceptual provisions that will be used in this contribution, as shown in Figure 1.

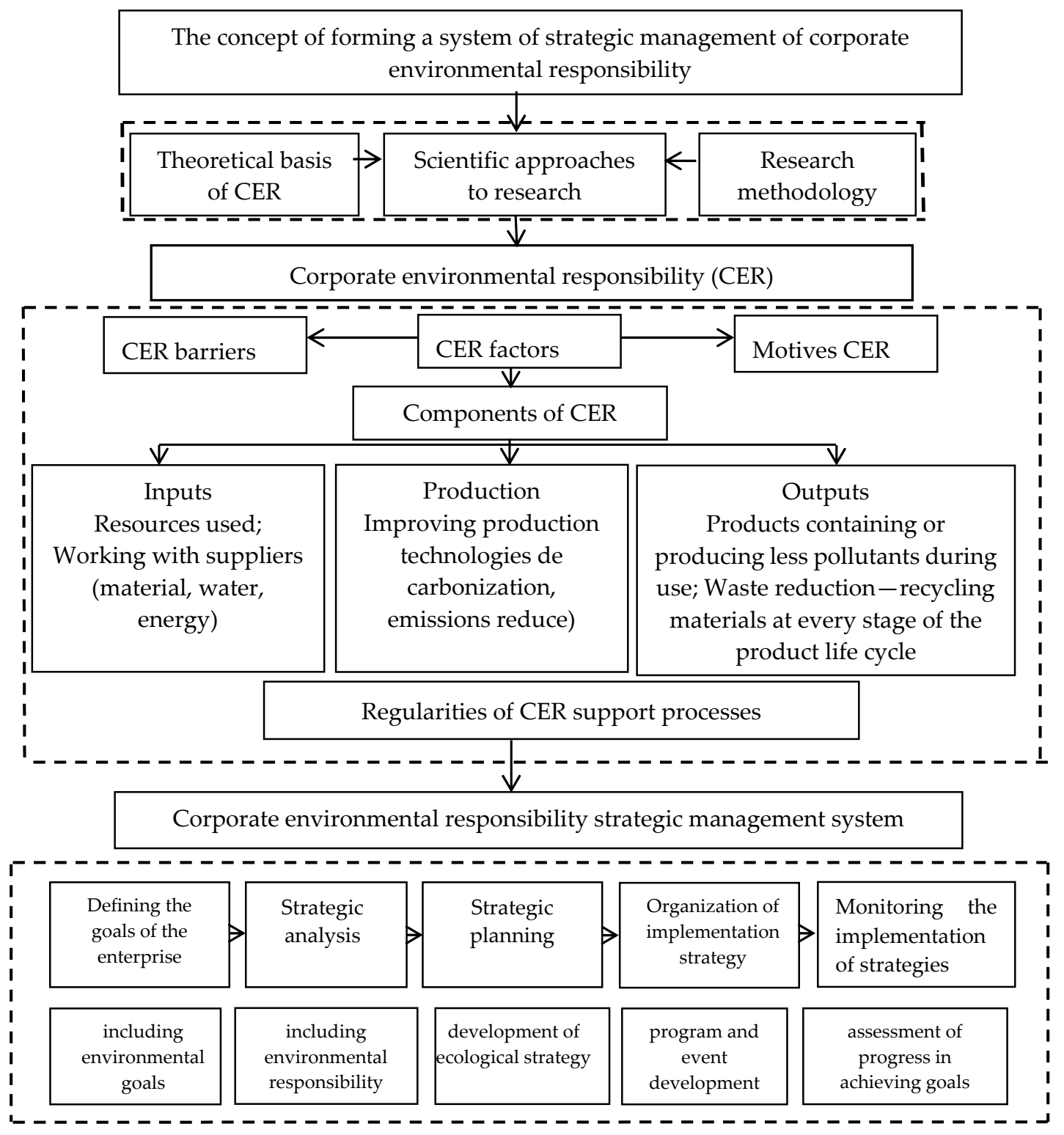

Figure 1. Concept for the strategic management of corporate environmental responsibility.

The main purpose of developing the concept for corporate environmental responsibility (CER) management is to form a set of theoretical and methodological provisions, as well as practical recommendations, for creating and ensuring the effective functioning of the CER strategic management system. 
Ensuring environmental responsibility of a certain level is dependent on internal management decisions. Respectively, the development of conceptual provisions will scientifically substantiate the content of management processes, implement the positive experiences of companies with a high level of environmental responsibility, and support management processes on an ongoing and systematic basis.

The proposed concept for corporate environmental responsibility above encompasses the:

- Theoretical level-provides a synthesis of provisions that determine the scientific basis for understanding the studied processes;

- Methodological level — enables the formation of the methodical provisions for the research;

- Practical level-provides a set of measures for the practical implementation of the concept, based on a comprehensive analysis.

The field of CER management includes the constituent elements of CER, CER factors, and the regularities of CER support processes, and the proposed research to determine the informational basis for management decisions. The chain of environmentally responsible behavior of a company includes the following basic elements-inputs (resources used by the company), internal processes (technological processes for processing resources and production), and outputs (products and their environmental characteristics, waste and the company's ability to reduce it)—as shown in Figure 1, which should be seen as the basis of the strategic management process.

\subsection{Theoretical Basis of the Study}

It is the shared opinion of the authors that sustainable development theory, resource theory, theories on investments, innovations, organizations, and strategic management form the theoretical basis for improving the strategic management system for corporate environmental responsibility. By synthesizing the contents of such theories, it is possible to determine the basic development patterns of a company's processes of interaction with its environment with a view to its long-term economic efficiency.

Sustainable development theory, based on the macro level in response to the complexity of the functioning and development of society [27-29], identifies an increase in the requirements for companies to incorporate environmental goals into their overall system of development goals and to consider them of equal importance to their economic and social goals. The implementation of the concept of sustainable development manifests itself in the separation of a company's interactions with its external environment in a separate important subject of management and by elevating this interaction to a management level of responsibility.

The issues of corporate responsibility and sustainable corporate development are comprehensively based on the UN Global Compact [30], which defines the goals and principles of responsible corporate behavior in the following areas: human rights, labor standards, environment, and anti-corruption. Those companies that operate globally and who adhere to the Compact's principles and adopt a strategy of corporate responsibility and sustainability see a significant effect on all areas of their business.

According to resource theory [31-34], resources determine the economic results of activities. A company's resources are increasingly being considered [31,35] from the strategic point of view. Grant [31] stressed that resources and capabilities are the basis of a company's long-term strategy, citing two main arguments to support this conclusion: (1) resources and capabilities determine the main direction of company strategy, (2) resources and capabilities are the main sources of company profits.

However, even though in today's environment the acquisition of intellectual resources is considered of strategic importance for the sustainable development of companies, in reality the emphasis remains on the efficient use of natural resources. It is for this reason that the environmental responsibility management system should aim to systematically improve the efficiency of natural resource use. By reducing the consumption of natural resources, a company is already fulfilling its responsibility. Accordingly, the economic system's ability to use resources and external opportunities to achieve a 
strategic goal is an important condition for increasing the level of environmental responsibility in the long run.

In terms of the content of investment and innovation theories, both activities are important prerequisites for ensuring a company's ability to improve its level of environmental responsibility.

If a company invests heavily in fixed assets or innovations, it is contributing to increasing its level of environmental responsibility through the introduction of resource-saving technologies and the development of new environmentally friendlier products. The corporate goal of increasing environmental responsibility therefore depends on a company's investment and innovation potential and goals.

Environmental (green) investments, according to investment theory [36-38], are occupying an ever increasing place in the structure of real investments. In the past, such investments were automatic as a result of the process of upgrading to newer equipment, thereby saving resources. However, at the present time, investment activities are being subordinated for the prime purpose of achieving environmental goals. The composition of environmental investments has expanded-it is important not only to invest in the use of natural resources, but also in the reproduction of natural resources and the protection of natural objects.

A new powerful direction in the development of innovation theory $[28,29,39-41]$ is the study of eco-innovation. Eco-innovations, from the point of view of industrial companies, includes green production processes, innovative products manufactured using natural resources, management methods and tools for the prevention of environmental pollution, optimization, the replacement of used resources, and innovative sustainable development policy. Eco-innovations are aimed at reducing the impact of companies on the environment. However, the introduction of eco-innovations is not always a priority for manufacturers because it is accompanied by increased costs for reorganizing production processes, changes in technology, and updating the material and technical base.

It should be noted that a company's affinity for green investments and innovations should be considered promising, as should the strategic direction of the company's development, and that this should be integrated into the overall system of management decisions accordingly.

The concept of sustainable development is quite multifaceted. Within this context, ensuring sustainable long-term development is a complex management task that requires a holistic strategic vision, the content of which should take into account the theory of organizational development [42-48].

At different stages of a company's development, various key drivers are used, particularly material resources, investments, innovations, intellectual capital, and others. Under current conditions, an important sign of the sustainable development of a company is not only the achievement of its own economic goals and those of its stakeholders, but also how it ensures its accountability to society.

Synthesis of the evolution of the main goals and drivers of company development, which are embodied in the lifecycle stages, allows us to identify the following main stages of organizational transformation: efficient company, competitive company, socially responsible company, environmentally responsible company. If we consider the proposed stages of company development through the prism of the pyramid of corporate social responsibility, as proposed by Carroll [46], we can distinguish several types of companies according to the levels of implementation of the principles of environmental responsibility in management processes, as shown in Figure 2.

The presented scheme reflects the importance of a company's environmental goals with respect to its market status. Given the strategic importance of the need to increase the level of business responsibility towards society and sustainable and balanced development, as well as the imagery associated with the aforementioned, it is necessary to apply more modern management approaches.

Within this context, management theory provides the answers to the questions about which direction must be followed to ensure environmental responsibility.

Of importance from the viewpoint of the development of management theory are: (1) the separation of such a component of the management system as strategic management with a focus on implementation, including the objectives of corporate environmental policy; (2) the 
implementation of the principles of strategic management in practice with regards to corporate environmental responsibility management in order to enable the consideration of development goals more comprehensively, in the long run, and within the context of modern societal demands.

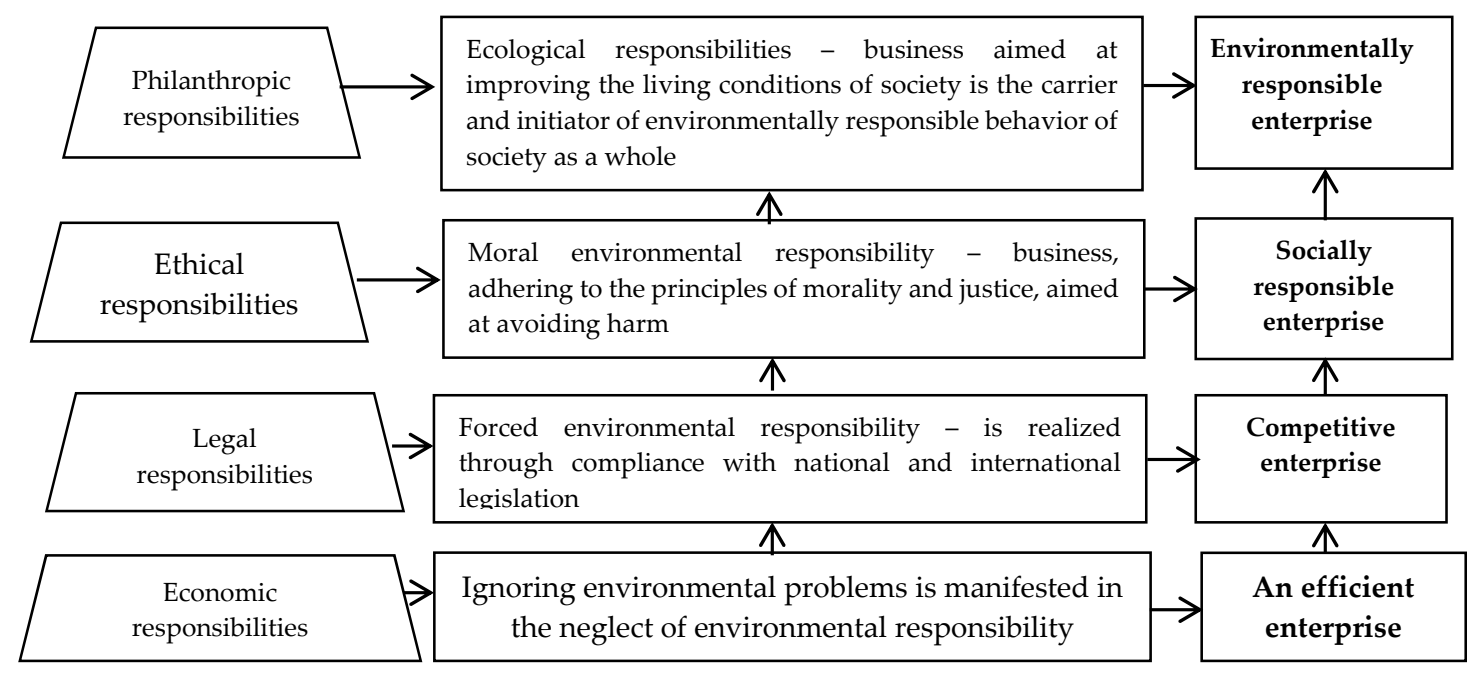

Figure 2. Environmental responsibility of a company according to lifecycle stages.

Based on the theoretical positions established in [7,35,49-51], and within the context of the implementation of strategic management approaches for corporate environmental responsibility management, it is expedient to take as a basis the following stages:

(1) Identification of development goals-the environmental goals are reflected in the key sustainable development goals of the company;

(2) Strategic analysis of the level and conditions necessary for increasing the environmental responsibility of the company-the focus is on research into the external environment and the forecasting of trends to determine the internal potential for increasing the environmental responsibility of the company;

(3) Strategic planning - this involves the development of a set of strategies, whereby environmental strategy is becoming increasingly important, for the meaningful and long-term determination of areas for improvement with regards to the company's interaction with the external environment;

(4) Implementation of environmental strategy — this involves assessing the risks of implementing the environmental strategy, the development of a program, measures, and key documents that will ensure the practical implementation of the strategy, as well as the development of policies, the allocation of resources, and the motivation of employees;

(5) Checking the implementation of the environmental strategy-a process of constant review prevents the company becoming trapped in its own irrelevant strategy.

This review of the content of scientific theories makes it possible to summarize the basic theoretical provisions for determining the concept for the strategic management of fixed assets of a company:

(1) The implementation of the concept of sustainable development determines the orientation of the company, including its environmental goals, which, in conjunction with economic and social goals, should be considered as important guidelines;

(2) Multifaceted manifestations of environmental responsibility (products, technologies) are a condition for the formation of long-term competitiveness and a positive image;

(3) Ensuring the appropriate level of environmental responsibility requires all internal subsystems and functional areas of the company to be environmentally oriented;

(4) Environmentally responsible companies become drivers of the formation of an environmentally responsible society. 
The strategic management system for CER is a mechanism for the alignment of processes within a company and within the context of global long-term trends in environmental management. Alignment also means harmonizing the pace of economic and environmental indicators. Accordingly, the basis for designing an environmental responsibility management system should be a proper analytical justification. It is for this reason that it is also necessary to generalize and improve existing methodological provisions for the analysis of the level of environmental responsibility of companies.

\subsection{Methodical Provisions for the Analysis of Corporate Environmental Responsibility}

The basis for designing and ensuring the effective functioning of a strategic management system for CER is appropriate informational support, which requires a comprehensive analytical methodology.

In general, there are several basic approaches to analyzing the level of environmental responsibility:

(1) Integrated approach—this involves the calculation of generalized indicators, for example:

- Environmental Sustainability Index (ESI) according to the World Economic Forum [52], which reflects the overall progress towards environmental sustainability, and which allows for cross-national comparisons;

- Dow Jones Sustainability Indices (DJSI) [53,54], which provides an analysis of corporate economic, environmental, and social indicators, and which includes general and specific industry criteria;

- Synthetic Indicator for Evaluating Environmental Performance (SIEEP), which is based on four criteria: waste and wastewater management and water protection, waste management and protection of the Earth's surface, air pollution and climate control, nature conservation and the promotion of pro-environmental behaviors [55-58];

(2) Fragmentary approach - this involves the study of individual indicators of environmental responsibility within the general monitoring system of the level of sustainability of companies, along with the analysis of economic indicators and indicators of social responsibility. Companies compile a report on sustainable development, which includes a separate section containing information on environmental indicators;

(3) Econometric approach - this involves the study of existing relationships between environmental responsibility indicators and financial and economic performance indicators.

Many empirical studies into the impact of environmental values on company activities confirm the emergence of multifaceted positive effects on the environment and society $[55,57,59,60]$.

The basis of the study of environmental responsibility indicators and their impact on economic performance is the concept of environmental efficiency, which focuses on reducing resource consumption, reducing the negative impact on the environment, and increasing the cost of production. The main indicators of eco-efficiency are defined in Table 2.

The presented indicators do not allow for a comprehensive analysis of a company's impact on the environment and therefore do not fully provide informational support for management decisions on environmental responsibility. In addition, the basic approach to the assessment of eco-efficiency, which is used in this methodology, is to compare the results of the company, in terms of products and their impact on the environment for example, which is difficult to distinguish. After all, a company's impact on the environment is more complex and therefore requires a variety of analytical studies. It is for this reason that the methodological provisions formed by the use of both integrated and fragmentary approaches need clarification. 
Table 2. Methodological approach for the assessment of eco-efficiency.

\begin{tabular}{cc}
\hline General Approach for the Assessment of Eco-Efficiency \\
\hline Eco-efficiency $=$ & $\begin{array}{c}\text { Enhancing quality } \\
\text { Value of a product }\end{array}$ \\
$\begin{array}{c}\text { Environmental impact of a product } \\
\text { Reducing impact }\end{array}$ \\
\hline $\begin{array}{c}\text { Calculation of Product Eco-Efficiency (Factor T) } \\
\text { product/eco-efficiency of benchmark product }\end{array}$ & $\begin{array}{c}\text { Calculation of Business Process Eco-Efficiency } \\
\text { eco-efficiency = business process eco-efficiency in } \\
\text { assessed year/business process } \\
\text { eco-efficiency in benchmark year }\end{array}$ \\
\hline
\end{tabular}

Resource: [61,62].

Topical methodological issues concerning the analysis of environmental responsibility include the identification of key stages of analysis, the formation of an optimal set of indicators for each stage of the analysis, the choice of information processing methods, and the determination of criteria for assessing positive trends.

The need for a comprehensive analysis of environmental responsibility is increasingly important because the results obtained:

(1) Reflect the achievements of the company in this direction, which is important for a growing number of stakeholders and society as a whole;

(2) Allow comparisons to be made with other competitors regarding the company's interactive processes with its external environment;

(3) Enable substantiation of the company's strategic development goals, including environmental ones.

This multi-criteria task requires the application of a set of approaches and methods to research and optimize management.

In our opinion, and within the context of improving the level of information support for strategic environmental responsibility management, it is advisable to apply an integrated approach to micro-level analysis, and within a fragmentary approach to define a clear algorithm for calculating the most common indicators to ensure comparability of such analysis.

On the basis of the main generalizations of the methodological approaches in $[56,57,60]$, and based on our own research, the following algorithm for the analysis of a company's environmental responsibility is proposed, as shown in Figure 3.

The presented algorithm, as the principle basis for ensuring the complexity of monitoring, will contribute to the formation of the necessary information base for improving the efficiency of the environmental responsibility management system.

Management decisions regarding the impact on the enterprise and on the environment must take into account the global challenges facing companies in connection with the implementation of the concept of the sustainable development of society, must be based on the experience of industry leaders, must be formulated in terms of multifaceted goals, and must ensure a balance between environmental, social, and economic goals. This understanding of the functions of a company's environmental responsibility management system determines the key areas of analysis, which are reflected in the main stages.

The complexity of the level of CER, if the emphasis is placed on responsibility, i.e., the conscious attitude of the company towards its own social role and environmental impact, determines the need to justify a set of key quantitative and qualitative analysis indicators. Assuming the first and second proposed stages operate with higher quality indicators, the third stage therefore requires the systematization of the key indicators used in the process of quantitatively assessing environmental responsibility, as shown in Table 3. 


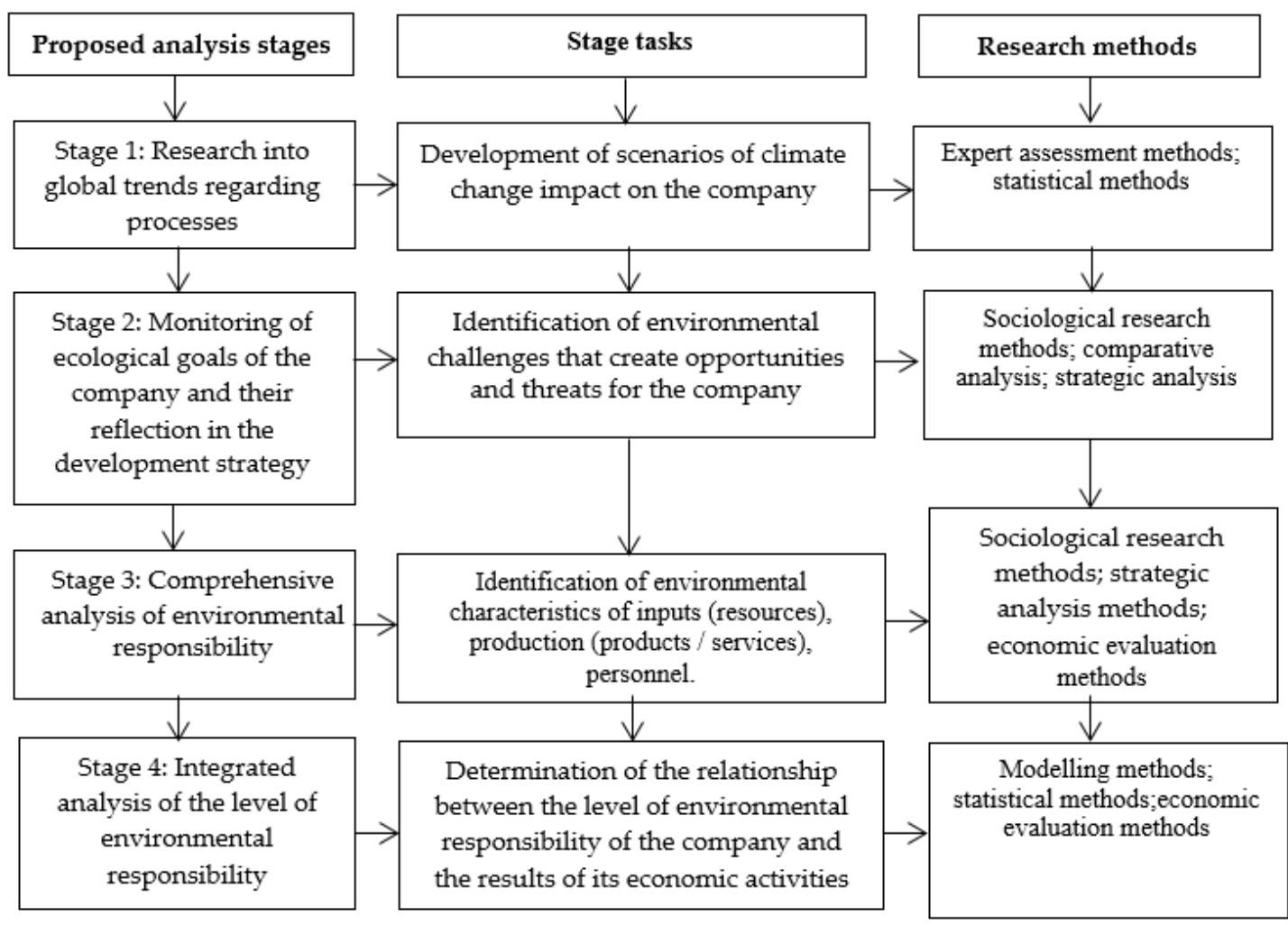

Figure 3. Methodological provisions for analysis of the level of environmental responsibility.

Table 3. Indicators for the analysis of ecological responsibility.

\begin{tabular}{|c|c|}
\hline & Indicators \\
\hline I & Analysis of rational use of resources \\
\hline 1 & Gross energy consumption \\
\hline 2 & Consumption of non-renewable fuels \\
\hline 3 & Own energy generation \\
\hline 4 & Share of own energy generation in total energy consumption \\
\hline 5 & Water consumption (difference between total intake and total discharge), thousand $\mathrm{m}^{3}$ \\
\hline 6 & Specific irreversible water consumption, $\mathrm{m}^{3} / \mathrm{unit}$ of output \\
\hline II & Analysis of environmental activities of the company \\
\hline 1 & Number of environmental measures \\
\hline 2 & Costs of environmental measures (indicators of costs and investments) \\
\hline 3 & Investments in modernization of resources and energy-saving technologies \\
\hline III & Analysis of emissions and waste management (air, water, land) \\
\hline 1 & Emissions of pollutants into the atmosphere \\
\hline 2 & Direct emissions of carbon dioxide, million tons of $\mathrm{CO}_{2}$-eq. \\
\hline 3 & Specific emissions of pollutants \\
\hline 4 & Analysis of the characteristics of the circular economy \\
\hline 5 & Waste going to landfill \\
\hline 6 & Use of waste in own production \\
\hline 7 & Amount of water consumption per closed water supply system \\
\hline 8 & Incl. share of water consumption per closed water supply system \\
\hline
\end{tabular}


The presented list of key indicators allows for a fairly detailed analysis of the level of environmental responsibility in terms of "input-production process-output". However, it can be significantly expanded depending on the needs of the analysis and the information required for management decisions on resource use, production processes, and product improvements.

Ensuring and increasing the level of environmental responsibility from the management point of view is a complex process of transforming inputs-resources into a set of outputs-products. This approach is taken as the basis for the proposed methodology. The company's impact on the environment should be identified at all stages, and it is for these that the company is responsible, as shown in Figure 4.

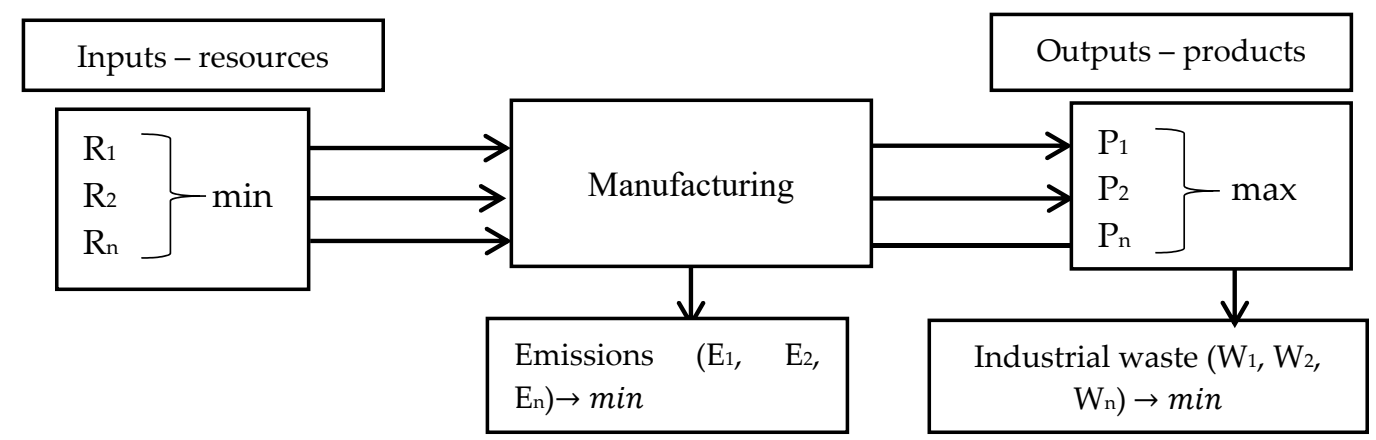

Figure 4. Structural and logical scheme for CER support.

It is therefore proposed to investigate the issue of eco-efficiency from the point of view of intra-oriented analysis, i.e., the study of the processes of eco-efficiency, as shown in Table 4.

Table 4. General approach to the analysis of environmental responsibility.

\begin{tabular}{ccc}
\hline Inputs-Resources & Production & Outputs-Products \\
\hline Use of safe materials & $\begin{array}{c}\text { Investments in fixed assets (resources } \\
\text { and energy-saving technologies) }\end{array}$ & Production \\
\hline Energy consumption & $\begin{array}{c}\text { Investment in environmental } \\
\text { protection }\end{array}$ & Emissions into the atmosphere \\
\hline Water consumption & Costs of environmental measures & Volume of industrial effluents \\
\hline Signs of environmentally responsible behavior of the company \\
\hline $\begin{array}{c}\text { Peduction of resource consumption } \\
\text { Reduction of resource costs per unit of } \\
\text { output }\end{array}$ & $\begin{array}{c}\text { Increasing investment in } \\
\text { resource-saving technologies } \\
\text { Increase the cost of environmental } \\
\text { measures }\end{array}$ & $\begin{array}{c}\text { Increasing the volume and share } \\
\text { of eco-friendly products }\end{array}$ \\
\hline
\end{tabular}

Input indicators refer to the volumes of used natural resources; production indicators characterize the processes for the transformation of resources into production results (products, waste, emissions, etc.), as well as the conditions for the provision thereof; output indicators include production volumes and emissions.

When applying the principle of efficiency to the analysis of the level of environmental responsibility, which means comparing the results and costs, as done in the process of calculating eco-efficiency, it is advisable to use the reverse approach and calculate the resource intensity of products in terms of all types of resources used.

The coefficient of the resource intensity of products reflects the costs of the resources (materials, energy, water, etc.) per unit of output:

$$
C_{n}^{r}=\frac{R_{n}}{Q_{i}}
$$


where

$C_{n}^{r}$-is the resource intensity ratio for a certain n-type of resource (materials, energy, water, etc.);

$R_{n}$ - the amount of resource use of a certain $n$-type;

$Q_{i}$-volume of production.

It is expedient to calculate the indicator of resource intensity both on natural and on cost indicators.

It is advisable to consider the complex results at the output stage, i.e., both finished products and waste. Accordingly, it is advisable to calculate the indicator of waste generation, which is calculated as the ratio of certain wastes to the volume of production:

$$
C_{n}^{w}=\frac{W_{n}}{Q_{i}}
$$

where

$C_{n}^{w}$-is the waste intensity ratio for a certain n-type of waste (materials, energy, water, etc.);

$W_{n}$-the amount of waste resource use of a certain $n$-type.

No less important is the calculation of the coefficient of waste generation per unit of raw material used for the production of one unit of production.

It is proposed to calculate the generalized coefficient of eco-efficiency in the ratio of waste and resources as the arithmetic mean of the partial indices for all types of resources:

$$
I_{e c o}=\frac{1}{N} \sum_{n=1}^{N} C_{n}^{w, r}
$$

For the results of the analysis to have a high level of informativeness and comparability, it is necessary to:

(1) Use absolute indicators, i.e., per unit (conditional unit) of production or per certain comparable value, which enables the establishment of the scale of the studied processes;

(2) Analyze the dynamics of the indicators, calculating the absolute and relative deviations.

When it comes to increasing environmental responsibility, the dynamics of the selected indicator values should tend to fall both in absolute and relative terms, which means a decrease in the negative impact of the company on the environment.

The use of absolute indicators enables comparisons to be made with those of similar competing companies, thereby enabling the identification of key areas for improvement.

The task of increasing the level of environmental responsibility in practice is determined by a company's ability to solve the complex problem of maximizing production volumes, while minimizing the possible costs of resources and minimizing the negative impact on the environment.

The calculation of relative indicators enables the ratio of the dynamics between inputs, internal processes, and outputs to be established.

The sustainable long-term growth of a company, which should occur against the backdrop of an increasing level of environmental responsibility, can be characterized by certain proportions between the main indicators. The most general absolute indicators from which to draw sufficiently informative conclusions about the general trends regarding the sustainable environmental responsibility and sustainable growth of a company are resources $(r)$, production $(q)$, profit $(p r)$, investments in environmental measures $\left({ }_{i n v}{ }^{e c}\right)$, and waste $(w)$.

An increase in the level of environmental responsibility of a company will be evidenced by the dynamics of the ratio between the following studied processes-the growth rate of production $\left(T_{q}\right)$ should exceed the growth rate of resources $\left(T_{r}\right)$, which in turn should exceed the rate of waste generation $\left(T_{w}\right)$.

Reducing the negative impact on the environment, which is the responsibility of a company, depends on the costs of environmental measures and investments $\left(T_{i n v}{ }^{e c}\right)$, primarily with regards to 
resource-saving technologies, in the quality of production, in terms of meeting world environmental norms and standards, in the waste processing (utilization) technologies, and on the dynamics of profit $\left(T_{p r}\right)$.

In general, the ratio of key indicators for a company's environmentally responsible behavior, balanced with its economic goals, is as follows:

$$
T_{w} \leq T_{r} \leq T_{q} \leq T_{p r} \leq T_{\text {invec }}
$$

These are the optimal proportions, which, despite some criticism from scientific quarters, makes it possible to streamline the dynamics and establish a cause-and-effect relationship between the indicators. However, although the indicators of eco-efficiency presented in Table 2 are of a generalized nature, they also show certain shortcomings in terms of reflecting the content and versatility of a company's impact on the environment depending on their economic results.

\section{Results and Discussions}

What follows is an analysis of the key aspects of incorporating the concept of environmental responsibility into the strategic management systems of modern companies based on a strategic analysis of key external and internal conditions. This is done on the basis of a comprehensive study into the level of environmental responsibility in global automotive companies and the substantiation of basic management decisions in order to form an environmental responsibility management system.

\subsection{Research into Global Environmental Challenges and Sustainable Development Goals}

Global environmental problems are a source of both risks and business opportunities. That is why an increasing number of companies worldwide, especially if their activities are global, are actively monitoring global challenges from the standpoint of their importance to all stakeholders and directly to the company.

Automotive companies are largely responsible for the world's environmental situation, as their products and, in fact, all their activities generate $\mathrm{CO}_{2}$ emissions. This implies that solving the problem of global warming, which has become particularly relevant in recent years, falls under corporate governance.

Any study of global environmental trends involves taking into account forecasts of the state of the environment for decades to come, political trends in solving environmental problems, and the role of interstate regulation.

Global environmental problems are the result of the increasing pace of human economic activity and neglect of the natural environment. The dynamics of global GDP compared to $\mathrm{CO}_{2}$ emissions confirms this conclusion, as shown in Figure 5.

Since the middle of the twentieth century, scientific and technological progress has significantly increased the impact of human activities, whilst failing to tackle the negative consequences on the environment. Emissions, such as $\mathrm{CO}_{2}$, are gradually increasing, both in developing countries that have intensified their industrial development and in most developed countries.

An analysis of the dynamics of emissions and the volume of energy consumption per capita is more indicative hereof, as shown in Figure 6. Despite all the declarations to increase the level of environmental responsibility, evidence shows that there has been a gradual increase over time in $\mathrm{CO}_{2}$ emissions and energy consumption per capita.

The growing manifestation of environmental problems at the global level has led to governments of more and more countries consolidating their positions with regards to the need to increase the level of environmental responsibility of all countries and their economic entities by disseminating and complying with international and national regulations. However, there are still differences in the implementation of enforcement mechanisms of accepted environmental standards in developed and developing countries. Furthermore, for many companies in developing countries, compliance with 
certain environmental standards requires significant investment in updating technological processes, which is unattainable for them. Such conditions, respectively, require government support and adapted approaches. This does not concern the abolition of environmental performance standards, but the achievement of better results by creating the conditions and putting in place the incentives to increase environmental responsibility, stimulate eco-innovation, unify management practices, and enhance the cooperation between government and business.

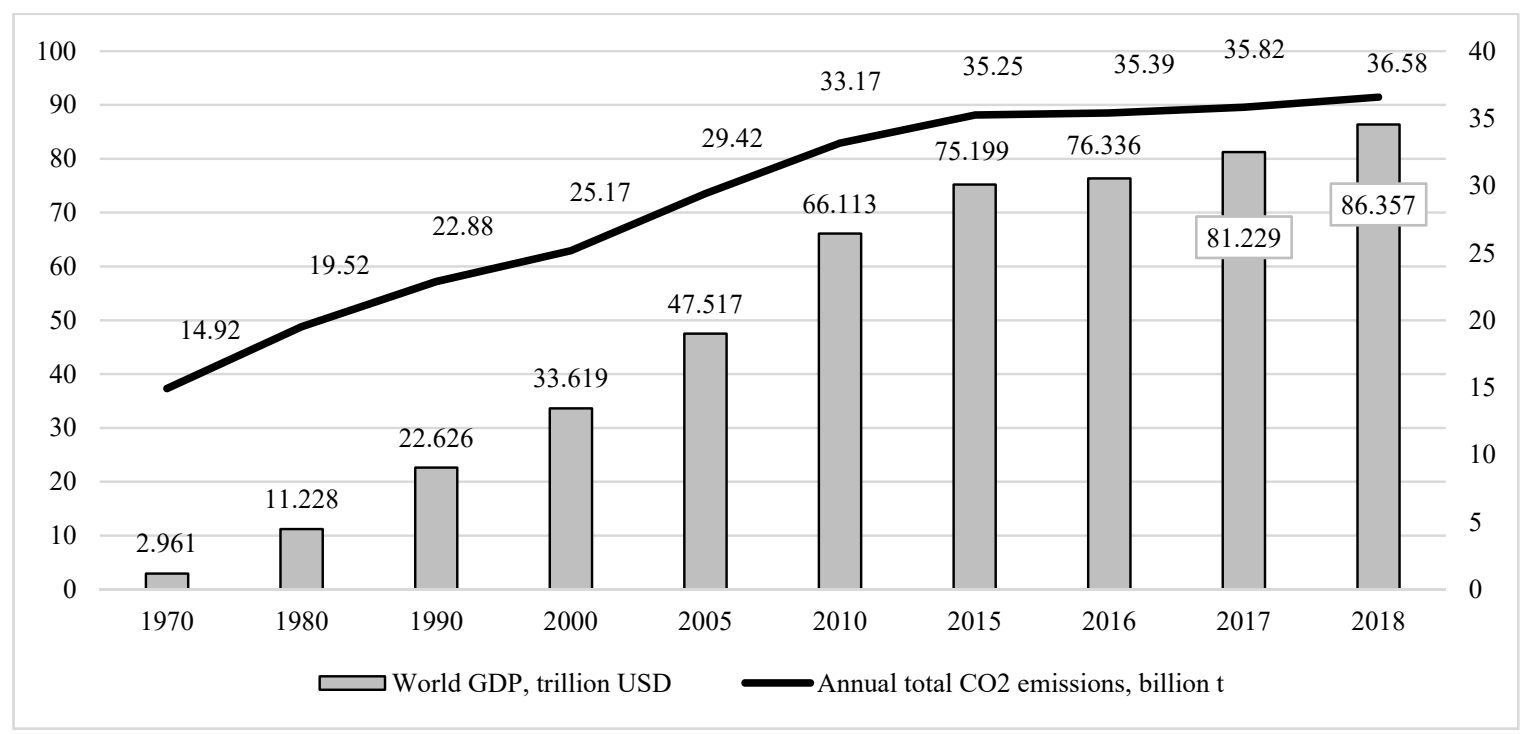

Figure 5. Dynamics of global GDP and $\mathrm{CO}_{2}$ emissions [2].

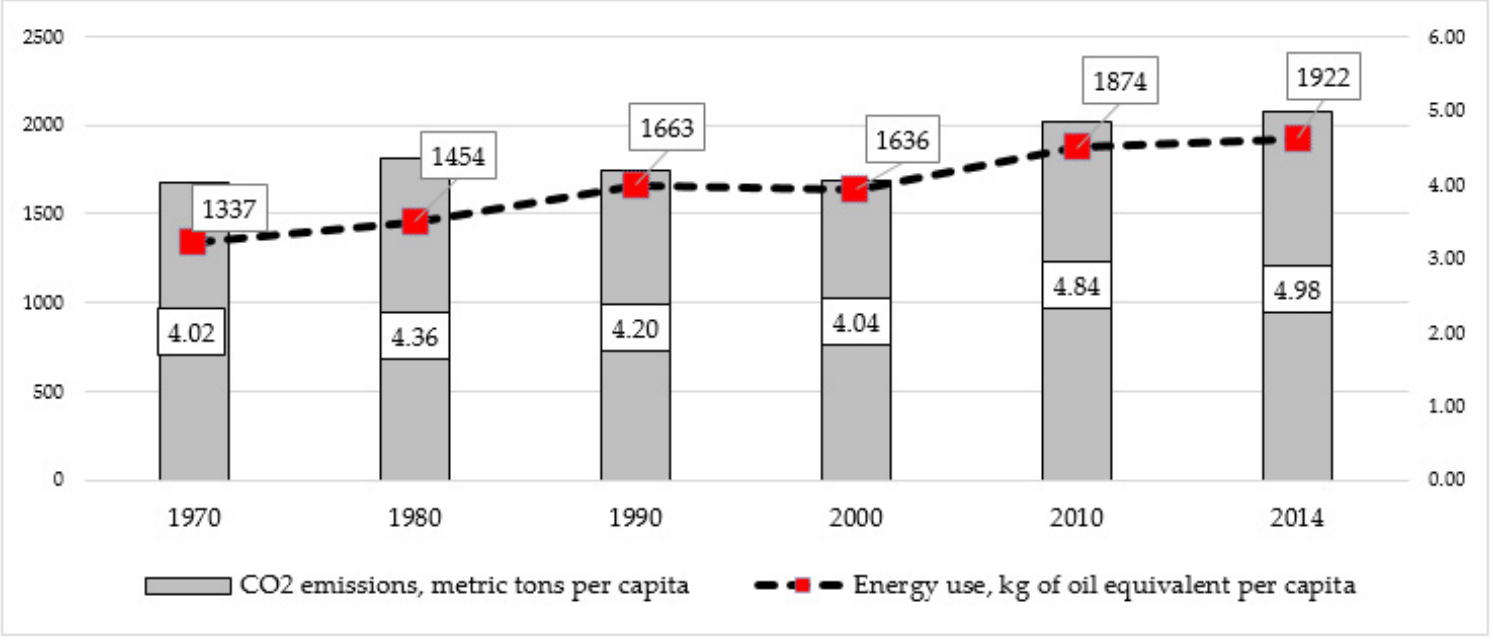

Figure 6. $\mathrm{CO}_{2}$ emissions and energy consumption per capita [2].

The new concept of regulating environmental responsibility aims to create the conditions and put in place the incentives to encourage companies themselves to improve their behavior towards the environment.

Key documents in the pursuit of this goal include the UN Global Compact, the objectives of which are to set targets for environmental responsibility and outline companies' possible contribution to the environment, and the Paris Climate Agreement, which saw representatives of almost 200 countries pledge to keep global warming well below $2^{\circ}$ Celsius, monitor emissions, and report on progress on this issue every 5 years.

The issue of interaction with the environment is therefore the focus of strategic management at the: 
(1) (International) institutional and organizational level because it is impossible to solve problems alone, even for a large country;

(2) State level because the balanced environmental policy of a state determines the characteristics of its environmental activities at the micro-level and forms the basis for interstate consensus on environmental protection;

(3) Company level because it is through environmental policy development that a company looks at and adopts internal standards for production technology, the eco-friendliness of its products, and waste processing.

An exceptionally multi-level approach and the consolidation of government and business efforts can reverse the negative impact on the environment and ensure a real transition to responsible behavior.

By specifying company development goals in response to existing global challenges, it is easier for companies to understand their responsibilities with regards to the sustainable development of society.

The consistency of such goals with the UN Agenda and the real challenges and goals related to a company's activities is presented in Figure 7.

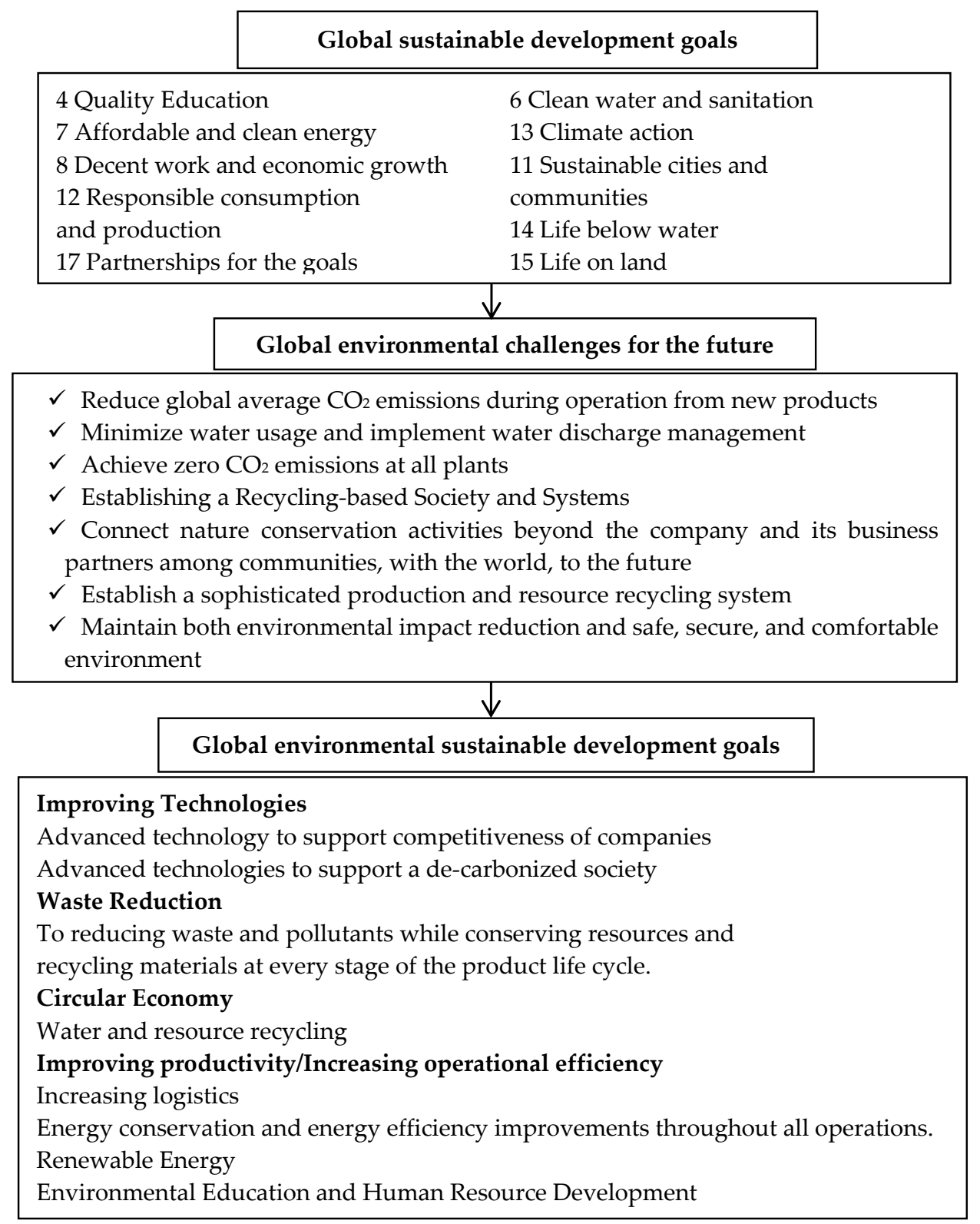

Figure 7. Global goals and challenges as the basis for corporate environmental responsibility management. 
The complexity and scale of the challenges facing humanity in solving global environmental problems require an increase in the level of environmental responsibility of virtually all economic entities. The greening of a company's economic activities means the use of alternative raw materials, the imposition of environmental requirements, the introduction of ecologically cleaner technological processes, taking into account the requirements of consumers, and solving the problem of waste disposal and recycling.

\subsection{Monitoring the Environmental Goals of Companies and their Incorporation in Development Strategy}

The majority of company development goals relate to market share, income, and profit. However, environmental responsibility has become important for competitiveness and has therefore infiltrated all areas of a company's activities.

The market mechanism has a strong motivational character with regards to increasing the level of environmental responsibility. The intensification of competition elevates this issue to being an important factor. The eco-friendliness of products and the greening of production processes therefore provide a company with important competitive advantages. In this process, the influence of consumers manifests itself in the form of unified requirements regarding the environmental performance of products, whilst competitors determine the technological trends within their industry, i.e., the required level of investment for the introduction of eco-technologies and closed-loop production processes. The creation of competitive advantage based on environmental responsibility is a long-term strategic task for a company because it requires significant investment. However, large powerful companies are increasingly pursuing environmental goals, given the growing social and humanitarian significance thereof. This is exactly the situation in the global automotive market.

A company's chosen level of environmental responsibility is a management decision, which is always a compromise between its economic, social, and environmental interests. However, whereas in the past, economic, and then social goals prevailed, it is now environmental goals that have the greatest value. In general, this is a rather complex management process. Ensuring environmental responsibility requires significant company efforts, especially financial, while the results are in the plane of social significance.

It is for the aforementioned reason that, at present, environmental goals are actively prescribed to substantiate the mission and development strategy of modern companies. These goals are increasingly being aligned with global goals and not only to internal business processes-they go beyond corporations, thereby becoming the drivers of an environmentally responsible society.

Leading automotive companies are aware of their responsibilities to society, the environment, and future generations. Their development goals therefore take into account the key principles of sustainable development, as defined by the UN Global Compact, as shown in Table 5.

As previously stated, a company's chosen level of environmental responsibility is a management decision, one which requires the mobilization of all the company's subsystems to identify priority areas for transformation. Based on the environmental goals and identified areas for transformation, an environmental action plan must be developed and drawn up with targets, quantitative indicators, and time horizons. This targeted accountability program is an important tool for managing environmental responsibility because it confirms that all stakeholders follow the concept of sustainable growth, as well as ensures the incorporation of the environmental goals into all aspects of a company's operational activities.

In general, the environmental goals of leading companies are heavily influenced by global environmental challenges, as is the case in the automotive industry, which are taken as the basis for the strategic management of environmental responsibility. In developing a general strategy for company development, key environmental goals are identified, which are clearly specified in environmental strategies. All the above suggests that hypothesis $\mathrm{H} 1$ has been confirmed. 
Table 5. Overview of environmental goals in corporate development strategies.

\begin{tabular}{ccccc}
\hline Nissan & GM & VW & Toyota & Ford \\
\hline $\begin{array}{c}\text { Realizing a } \\
\text { zero-emission, } \\
\text { zero-fatality society }\end{array}$ & $\begin{array}{c}\text { Ge see a world } \\
\text { with zero crashes, } \\
\text { zero emissions, and } \\
\text { zero congestion }\end{array}$ & $\begin{array}{c}\text { Mission statement } \\
\text { “GoTOzero" }\end{array}$ & $\begin{array}{c}\text { Going beyond zero } \\
\text { environmental impact } \\
\text { and achieving a net } \\
\text { positive impact }\end{array}$ & $\begin{array}{c}\text { Zero-emission and } \\
\text { zero-impact } \\
\text { emission vehicles }\end{array}$ \\
\hline
\end{tabular}

Climate change, resource dependency (energy, materials), air quality, water scarcity, environmental compliance, waste

Targets

To achieve carbon neutrality by 2050 . To achieve zero air emissions.

To use 100 percent renewable energy by 2035 .

To make zero water withdrawals for production processes.

To use freshwater for human consumption only.
To achieve zero waste to landfill. To eliminate single-use plastics from operations by 2030 .

To use recycled and renewable plastics.

To use of renewable energy to create a decarbonized society by 2050 .

$\frac{\text { Environmental Action Plan }}{\text { Source [62-66]. }}$

\subsection{A Comprehensive Study of Environmental Responsibility}

A comprehensive study of environmental responsibility will now be conducted on the basis of the data presented in Table 6 relating to Volkswagen, General Motors (GM), and Toyota.

Table 6. Initial data for the analysis of the level of environmental responsibility.

\begin{tabular}{|c|c|c|c|c|c|c|}
\hline Indicator & 2010 & 2016 & 2017 & 2018 & 2019 & $\% 2019(2018)$ to 2010 \\
\hline \multicolumn{7}{|l|}{ Volkswagen } \\
\hline $\begin{array}{l}\text { Vehicle sales } \\
\text { (in thousands of units) }\end{array}$ & 7278 & 10,391 & 10,777 & 10,900 & 10,956 & 50.5 \\
\hline \multicolumn{7}{|l|}{ Energy consumption, (in $\mathrm{kWh} /$ vehicle) } \\
\hline Total & 2519 & 2089 & 2068 & 2038 & 2010 & -20.2 \\
\hline Electricity & 1197 & 1088 & 1060 & 1063 & 1051 & -12.2 \\
\hline Heat & 855 & 599 & 587 & 560 & 550 & -35.7 \\
\hline Fuel gases for production processes & 467 & 402 & 421 & 415 & 409 & -12.4 \\
\hline $\mathrm{CO}_{2}$ emissions (in million tons/year) & 8.04 & 9.51 & 9.11 & 8.20 & 7.57 & -5.8 \\
\hline $\begin{array}{l}\mathrm{CO}_{2} \text { emissions } \\
\text { (in } \mathrm{kg} / \text { vehicle) }\end{array}$ & 1096 & 883 & 810 & 720 & 675 & -38.4 \\
\hline $\begin{array}{l}\text { Fresh water volume } \\
\text { (in } \mathrm{m}^{3} / \text { vehicle) }\end{array}$ & 4.54 & 3.89 & 3.76 & 3.86 & 3.57 & -21.4 \\
\hline Wastewater volume (in $\mathrm{m}^{3} /$ vehicle) & 3.76 & 2.96 & 2.93 & 2.69 & 2.66 & -29.3 \\
\hline \multicolumn{7}{|l|}{$\begin{array}{l}\text { Waste for recycling } \\
\text { (in } \mathrm{kg} / \mathrm{vehicle)}\end{array}$} \\
\hline Non-hazardous waste & 33.28 & 38.42 & 42.07 & 47.05 & 52.91 & 58.9 \\
\hline Hazardous waste & 12.43 & 13.56 & 13.89 & 14.07 & 13.98 & 12.5 \\
\hline Metallic waste & 217.27 & 212.24 & 211.54 & 208.89 & 204.96 & -5.7 \\
\hline $\begin{array}{l}\text { R\&D expenditure } \\
\text { (in EUR millions) }\end{array}$ & 6.866 & 13.612 & 13.135 & 13.640 & - & 98.7 \\
\hline $\begin{array}{l}\text { Capital expenditures on property, plant, } \\
\text { and equipment } \\
\text { (in EUR millions) }\end{array}$ & 6.275 & 13.2 & 13.1 & 13.6 & - & 2.2 times \\
\hline $\begin{array}{l}\text { Environmental protection costs } \\
\text { General Motors }\end{array}$ & & & & & & \\
\hline
\end{tabular}


Table 6. Cont

\begin{tabular}{|c|c|c|c|c|c|c|}
\hline Indicator & 2010 & 2016 & 2017 & 2018 & 2019 & \% 2019 (2018) to 2010 \\
\hline $\begin{array}{l}\text { Investment } \\
\text { (in USD/vehicle) }\end{array}$ & 13 & 10 & 16 & 14 & 9 & - \\
\hline $\begin{array}{l}\text { Operating costs } \\
\text { (in USD/vehicle) }\end{array}$ & 208 & 209 & 216 & 240 & 253 & - \\
\hline \multicolumn{7}{|l|}{ General Motors } \\
\hline $\begin{array}{l}\text { Total sales } \\
\text { (in thousands of units) }\end{array}$ & 9958 & 10,008 & 9600 & 8400 & 7718 & -22.5 \\
\hline $\begin{array}{l}\text { Total electricity consumption } \\
\text { (in } \mathrm{kWh} \text { ) }\end{array}$ & $38,456,432$ & $33,364,439$ & $30,313,931$ & $30,069,475$ & $27,112,428$ & -29.5 \\
\hline $\begin{array}{l}\text { Energy intensity } \\
\text { (in MWh/vehicle) }\end{array}$ & 2.31 & 2.00 & 1.96 & 2.03 & 2.13 & -7.8 \\
\hline $\begin{array}{l}\text { Water intensity } \\
\text { (in } \mathrm{m}^{3} / \text { vehicle) }\end{array}$ & 4.77 & 4.13 & 4.21 & 4.23 & 4.26 & -10.7 \\
\hline $\begin{array}{l}\text { Volatile Organic Compounds intensity } \\
\text { (in metric tons/vehicle) }\end{array}$ & 0.0038 & 0.0028 & 0.0025 & 0.0024 & 0.00235 & -2.1 \\
\hline $\begin{array}{l}\text { Waste intensity } \\
\text { (in } \mathrm{kg} / \text { vehicle) }\end{array}$ & 307 & 222 & 229 & 224 & 222 & -27.7 \\
\hline $\begin{array}{l}\text { R\&D expenditure } \\
\text { (in USD billions) }\end{array}$ & 4.259 & 6.600 & 7.300 & 7.800 & 6.800 & 59.7 \\
\hline $\begin{array}{l}\text { Capital expenditure } \\
\text { (in USD billions) }\end{array}$ & 4.200 & 8.300 & 8.300 & 8.700 & 7.500 & 78.6 \\
\hline \multicolumn{7}{|l|}{ Toyota } \\
\hline $\begin{array}{l}\text { Vehicle Sales } \\
\text { (in thousands of units) }\end{array}$ & 7237 & 8681 & 8971 & 8964 & 8977 & 24.0 \\
\hline $\begin{array}{l}\text { Energy consumption per unit produced } \\
\text { (in GJ/unit) }\end{array}$ & 9.36 & 9.12 & 8.76 & 8.85 & 8.61 & -8.0 \\
\hline $\begin{array}{l}\text { Total } \mathrm{CO}_{2} \text { emissions } \\
\text { (in million tons) }\end{array}$ & 8.0 & 8.09 & 8.46 & 8.42 & 8.29 & +3.6 \\
\hline $\begin{array}{l}\mathrm{CO}_{2} \text { emissions per unit produced } \\
\text { (in tons/unit) }\end{array}$ & 0.830 & 0.795 & 0.803 & 0.800 & 0.772 & -6.9 \\
\hline $\begin{array}{l}\text { Water usage per unit produced } \\
\text { (in } \mathrm{m}^{3} \text { /unit) }\end{array}$ & 3.4 & 2.9 & 3.1 & 3.1 & 3.2 & -5.9 \\
\hline $\begin{array}{l}\text { Waste volume per unit } \\
\text { (in } \mathrm{kg} / \text { unit) }\end{array}$ & 56.2 & 53.1 & 52.8 & 55.7 & 55.3 & -1.6 \\
\hline $\begin{array}{l}\text { R\&D expenditure } \\
\text { (in Japanese Yen (JPY) billions }\end{array}$ & 725.345 & 1055.6 & 1037.5 & 1064.2 & 1048.8 & 44.6 \\
\hline $\begin{array}{l}\text { Capital expenditure on property, plant, } \\
\text { and equipment } \\
\text { (in JPY billions) }\end{array}$ & 604.536 & 1292.5 & 1211.8 & 1302.7 & 1465.8 & 2.42 times \\
\hline $\begin{array}{l}\text { Net income } \\
\text { (in JPY billions) }\end{array}$ & 209.456 & 2312.6 & 1831.1 & 2493.9 & 1882.8 & 9 times \\
\hline \multicolumn{7}{|l|}{ Environmental protection costs } \\
\hline $\begin{array}{l}\text { Investment } \\
\text { (in JPY billions) }\end{array}$ & 23.4 & 18.9 & 76 & 63.6 & 77.2 & 3.3 times \\
\hline $\begin{array}{l}\text { Operating costs } \\
\text { (in JPY billions) }\end{array}$ & 324.4 & 451.0 & 425.1 & 392.6 & 432.4 & 33.3 \\
\hline $\begin{array}{l}\text { Investment } \\
\text { (in USD/vehicle) }\end{array}$ & 31 & 21 & 81 & 68 & 83 & - \\
\hline $\begin{array}{l}\text { Operating costs } \\
\text { (in USD/vehicle) }\end{array}$ & 431 & 500 & 456 & 421 & 463 & - \\
\hline
\end{tabular}

Source $[63,64,67]$.

The presented indicators, which were lifted from the companies' annual sustainability reports, indicate the lack of a uniform methodological approach to the analysis at the corporate level, which significantly complicates the study. 
The key areas of research were climate change, resource dependence, air quality, and water scarcity. Although these market leading car companies show significant progress in these key areas of environmental responsibility, some practices need further study and consideration. This notwithstanding, the analysis of the presented indicators enables us to draw the following main conclusions about the investigated companies:

(1) The total value of consumption of resources (inputs), including per unit of output, and in particular energy, has decreased;

(2) There has been a positive change in the dynamics of emissions and waste, which has decreased both in terms of total volumes and per unit of output, which implies an increase in the eco-efficiency of car production;

(3) Financial resources have gradually increased for protection of the environment both in terms of investment and operating costs (including per car).

All these key indicators indicate the extent to which the companies have developed, implemented, and ensured the effectiveness of their environmental strategies.

It is clear that in the period 2010 to 2019, the companies' interactions with the environment became greener in terms of supply, production, products, and waste, which implies that they are working towards establishing a future society in harmony with nature. This is evident from:

(1) The increase or decrease in the scale of activity, i.e., production volumes. This manifests itself through the corresponding dynamics (increase or decrease) of total consumption of material resources, energy, etc. Even though most of the companies spent less and used fewer materials year-on-year, the overall resource dependency remained quite high. For example, in Toyota, the ratio of recycled materials used is only $24 \%$, and in GM, only $20 \%$ of the energy consumed is produced from renewable resources. In GM's case, there is even increased materials consumption accompanied by a decrease in production. That is why, despite some of the achievements in this area, as confirmed by the consumption of materials and fuel per unit of output, the companies need to go even further to minimize their consumption of natural resources and increase their use of alternative sources of energy. Targeting these issues to reduce the companies' impact on the environment requires them to make progress on the efficient use of resources. This not only implies minimizing the use of new resources, but also intensifying the use of recycled ones. The overall scheme for improving resource efficiency should look like that proposed by Toyota: resource recycling, reusing recycled product, establishing a recycling-based society and systems.

(2) The greening of production processes, which manifests itself through the introduction of environmentally friendly technologies and the increased efficiency of resource use, thereby significantly reducing the negative impact on the environment. The high level of investment and innovation activity undertaken by automotive companies manifests itself in the introduction of eco-technologies, which has enabled them to, more or less, continuously reduce emissions per unit of output. Within this context, all the companies have set themselves the task of creating a low-carbon society, which is set out in specific goals-to achieve a 90\% reduction in $\mathrm{CO}_{2}$ emissions from new vehicles by 2050 and to achieve an 80\% reduction in $\mathrm{CO}_{2}$ emissions from corporate activities by 2050 .

(3) The improved management of waste, whereby the aim is to minimize the negative impact of the company on the environment. However, on this issue, it is clear that progress on reducing waste in the selected automotive companies is only gradual and slow, as evidenced by the general indicators of waste and per unit of output. Progress is slow because this involves high costs. The general strategy of the companies is very similar: reducing the amount of different types of waste, avoiding waste by optimizing production, and reusing waste to reduce recycling.

(4) The systematic management of environmental responsibility and the way in which financial resources are spent. The general indicators for capital investment and investment in innovation indicate that the companies are actively updating their fixed assets, improving their products, and greening, i.e., reducing the negative impact on the environment throughout the lifecycle of their products. 
Nevertheless, even though the costs of and investments in environmental protection, as the data show, are variable, they should definitely be considered investments in the development of future society.

A built-in internal factor that plays a role in increasing environmental responsibility in companies is investment in their technical and technological development. In one way or another, investments in fixed assets and/or R\&D, contribute to increasing the level of environmental responsibility of a company-the replacement of obsolete fixed assets by new companies automatically achieves better environmental performance and investment in $R \& D$ is primarily aimed at improving products, in particular in terms of their consumer characteristics and the need to improve environmental performance.

To properly understand the studied processes and ensure the strategic management of the key factors affecting a company's environmental responsibility, based on the example of Volkswagen, it is advisable to rank them and determine their impact using correlation analysis. As an effective indicator, it is proposed to use the total cost of environmental measures $(Y)\left(Y=f\left(x_{n}\right)\right)$. Important quantitative factors that affect environmental investment and costs include sales volume $\left(X_{1}\right)$, profit $\left(X_{2}\right)$, energy consumption $\left(\mathrm{X}_{3}\right), \mathrm{CO}_{2}$ emissions $\left(\mathrm{X}_{4}\right)$, capital expenditures $\left(\mathrm{X}_{5}\right)$, and research and development costs $\left(\mathrm{X}_{6}\right)$, as shown in Table 7 .

Table 7. Results of correlation analysis of the influence of key factors on environmental costs (for Volkswagen).

\begin{tabular}{ccccccccc}
\hline & $\begin{array}{c}\text { Cost of } \\
\text { Environmental } \\
\text { Measures }(\mathbf{Y})\end{array}$ & $\begin{array}{c}\text { Sales } \\
\text { Volume }\left(\mathbf{X}_{\mathbf{1}}\right)\end{array}$ & $\begin{array}{c}\text { Profit } \\
\left(\mathbf{X}_{\mathbf{2}}\right)\end{array}$ & $\begin{array}{c}\text { Energy } \\
\text { Consumption } \\
\left(\mathbf{X}_{3}\right)\end{array}$ & $\begin{array}{c}\mathbf{C O}_{2} \\
\text { Emissions } \\
\left(\mathbf{X}_{\mathbf{4}}\right)\end{array}$ & $\mathbf{b}_{3}$ & $\mathbf{b}_{\mathbf{1}}$ & $\mathbf{b}_{\mathbf{0}}$ \\
\hline $\mathrm{Y}$ & 1 & 0.78826 & -0.39025438 & -0.802878037 & -0.76083875 & -643.89 & 190.24 & $871,079.04$ \\
\hline $\mathrm{X}_{1}$ & - & 1 & -0.27692139 & -0.9610118 & 0.88007923 & 1974.846337 & 200.1409682 & $3,613,599.5$ \\
\hline $\mathrm{X}_{2}$ & - & - & 1 & 0.446954004 & -0.5227298 & 0.627017731 & $261,997.6415$ \\
\hline $\mathrm{X}_{3}$ & - & - & - & 1 & 0.88007923 & 5.883824079 & 7 \\
\hline $\mathrm{X}_{4}$ & - & - & - & - & 1 & $8.07764 \times 10^{11}$ & $4.80499 \times 10^{11}$ \\
\hline
\end{tabular}

There is no need to consider the quantitative values of all the indicators in the empirical research because their effect is duplicated. The reason for this is that capital expenditures and R\&D costs can be considered collinear to the volume of production, and the studied enterprises, including Volkswagen, are characterized as being highly attractive in terms of investment and innovation.

Among these factors, the volume of production has the most direct impact on environmental costs, whereby the impact of all the other factors is either less or vice versa.

The automotive companies selected for this study are not only industry, but also global leaders in terms of investment and innovation, investing USD 10-13 billion a year. At the same time, they demonstrate the progressive process of increasing the level of environmental responsibility. Based on the presented analytical data, it can be concluded that companies with a high level of investment and innovation activity are characterized by a high level of environmental responsibility, which is consistent with hypothesis $\mathrm{H} 2$. On the other hand, the opposite conclusion can be drawn-the studied companies, which are characterized by a high and growing level of environmental responsibility, have powerful and growing economic results. Besides this, the companies' interactions with the external environment produce many secondary benefits in terms of educational activities, improving the environmental situation in a region, and the setting of targets not only for themselves and their competitors, but also society as a whole, which partially confirms hypothesis H3.

\subsection{Integrated Analysis of the Level of Environmental Responsibility}

The sustainable development of a company requires balancing the dynamics of certain key indicators. The combination of sustainable development with growth in production and sales is attributed to the fragmentary approach. The authors' integrated dynamic approach (Equation (4)) characterizes some important relationships between economic and environmental indicators, which is fully consistent with strategic vision. 
The desire of owners and managers to achieve too high growth rates in a short period of time leads to a limited ability to generate new ideas, introduce innovations, and create competitive advantages. This can prove counterproductive, resulting in a slow company development rate, reduced investment attractiveness, business activity, value, etc.

On the basis of the corporate effects and the relationship between environmental indicators and economic results for the studied companies, a balanced model of key indicators for corporate environmentally responsible behavior was constructed. This forms the basis for understanding environmental management strategy problems and the content of the necessary measures that need to be taken accordingly.

The average annual growth rates of the economic and environmental indicators for the period 2010 to 2019 for the studied companies, and the resulting interpretation of the balance of development, are presented in Table 8.

Table 8. Dynamics of the relationship between environmental and economic indicators, 2010-2019.

\begin{tabular}{ccc}
\hline Company & Model & $\begin{array}{c}\text { The Relationship between Environmental and } \\
\text { Economic Results }\end{array}$ \\
\hline Nissan & $128.9 \geq 103.3 \geq 100.4 \geq 53.3 \leq 111.9$ & $\begin{array}{c}\text { Environmental indicators are unbalanced, } \\
\text { although increased investment can guarantee } \\
\text { economic stabilization. }\end{array}$ \\
\hline General Motors & $99.1 \leq 104.9 \geq 91.9 \geq 85.5 \leq 86.6$ & $\begin{array}{c}\text { Negative economic trends manifest themselves in } \\
\text { environmental indicators. }\end{array}$ \\
\hline Volkswagen & $98.1 \leq 98.6 \leq 100.5 \leq 106.0 \leq 105.8$ & Balanced ecological and economic development. \\
\hline Toyota & $96.5 \leq 97.3 \leq 1001 \geq 75.5 \leq 112.5$ & $\begin{array}{c}\text { A slight decrease in profitability is not a threat to } \\
\text { the environmentally responsible behavior of the } \\
\text { company. }\end{array}$ \\
\hline
\end{tabular}

The results of the analysis indicate that the environmental and economic sustainability indicators for the studied companies are unbalanced. This not only confirms the importance of incorporating the concept of sustainable development in the management process, but also the need for strategic management based on a well-formed and adaptive system to achieve economic, environmental, and social goals.

It is for this reason that the next stage of our study is the formation of a holistic vision for the components of the environmental responsibility management system.

\subsection{Designing a Strategic Management System for Environmental Responsibility Management}

Organizational measures are of particular importance for the implementation of the concept of environmental responsibility management. These measures should be focused on developing and implementing a strategy for company development. That is why, based on the generalization of the developed theoretical material and the experience of automotive companies, who can be considered leaders in the development of management tools, the authors have identified the following key elements of an environmental responsibility management system, as shown in Figure 8.

(1) Environmental policy aims to form the long-term vision of a company's behavior in its interactions with the external environment. This takes into account external challenges and the requirements placed on the company to act responsibly with regards to the environment. As a result, risk assessments are carried out and platforms for communication with society are formed.

(2) The analysis of environmental responsibilities contributes to the availability of comprehensive information with which to substantiate management decisions regarding environmental policy.

The purpose of the analysis should be to determine the multifaceted impact of the company on the environment through the prism of sustainable economic development, to study the impact of 
environmental responsibility on performance, and to justify the content of the necessary measures that need to be undertaken based on industry practice and best practices in leading companies.

(3) Incorporation of the strategic approach in management practice involves the development of a set of strategies for dealing with the external environment, in particular a climate change strategy, sustainable materials strategy, circular economy strategy, and renewable energy strategy. The implementation of each strategy is a complex process, so they should be considered in conjunction with each other.

(4) The environmental action plan is a specification of the formulated provisions of environmental policy and strategies, which enable the gradual implementation of certain goals, enable all those involved to be informed of the importance of following sustainable development principles, and enable environmental compliance across all business operations.

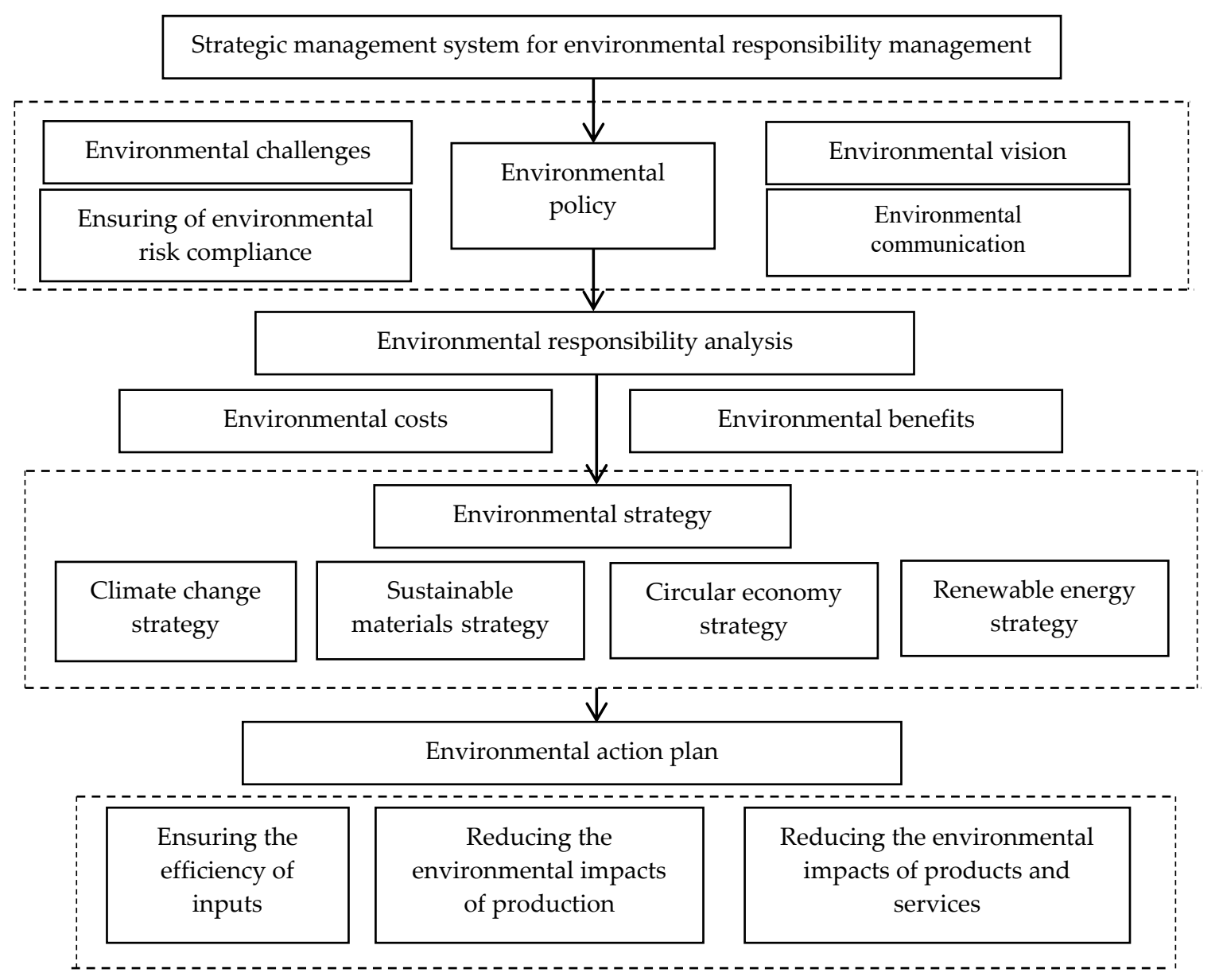

Figure 8. Components of the strategic management system for environmental responsibility management.

\section{Conclusions}

The implementation of sustainable development principles at the corporate level improves the existing system of environmental responsibility management and elevates it to a long-term strategic goal. The achievement of environmental goals by individual companies should be taken into consideration when seeking to solve global environmental problems, which highlights the relevance of the subject of research in this contribution.

Based on the generalization of existing scientific approaches to understanding the processes of a company's interaction with its external environment, the importance of the transition from the principles of efficiency to the concept of responsibility was noted, which means expanding individual companies' capacity to solve environmental problems. 
The study of existing scientific approaches for identifying the conditions necessary for forming a strategic system for corporate environmental responsibility revealed the mechanisms of influence of key factors on the external and internal environments, including environmental standards, competition, globalization, technical and technological development, and more.

Based on the understanding of the growing importance of corporate environmental responsibility in solving the environmental problems of society, the authors put forward a concept for forming a strategic management system for CER. The concept is based on existing scientific theories and provides a holistic vision of the nature of CER (factors, barriers, motives). A holistic approach to understanding CER involves the use of the input-throughput-output chain in the management process.

The application of a process approach to the strategic management system for CER enabled key stages to be identified: goal setting, strategic analysis, strategic planning, strategy implementation, and implementation control.

The key theoretical conclusion concerns the types of enterprises according to the level of their CER. It is the shared opinion of the authors that it is advisable to distinguish:

(1) Companies that subordinate environmental responsibility to the economic interests of modern development;

(2) Companies that provide a minimum level of environmental responsibility;

(3) Companies that provide a sufficient level of environmental responsibility and are focused on preventing harmful effects to the environment;

(4) Companies that determine the level of environmental responsibility in the industry and contribute to developing an environmentally responsible society.

Based on this classification, and with consideration for global and national trends concerning environmental responsibility management, there is a growing need for an effective system of strategic management of a company's environmental responsibility.

This contribution also systematized existing methodological approaches to the analysis of corporate environmental responsibility, which informed the authors' methodological provisions and systematized indicators in their own proposed approach for determining the balance of the dynamics of environmental and economic indicators.

The processes of environmental responsibility management were studied on the example of leading automotive companies in the industry. All the companies have a well-established environmental management system, which forms part of their sustainable development management system, which in turn is incorporated in the overall company management system. That is why their experience, based on the synthesis conducted in this study, can be the basis for improving approaches to increasing environmental responsibility. Based on analytical studies of the relationship between economic and environmental indicators, the authors proved the article's hypotheses.

A company's chosen level of environmental responsibility is a management decision. To permanently increase a company's level of environmental responsibility, the authors of this contribution put forward a strategic management system for CER, which includes an environmental policy, environmental strategy, and environmental action plan. The environmental goals and identified areas for transformation require the mobilization of all a company's subsystems and the development and drafting of an environmental action plan that contains targets, quantitative indicators, and time horizons. This targeted accountability program is an important tool for managing environmental responsibility because it confirms that all stakeholders follow the concept of sustainable growth, as well as ensures the implementation of the environmental goals into all aspects of a company's operational activities.

Author Contributions: All authors have contributed equally to all sections of this manuscript. All authors have read and agreed to the published version of the manuscript.

Funding: This research received no external funding.

Conflicts of Interest: The authors declare no conflict of interest. 


\section{References}

1. Malthus, T. An Essay on the Principle of Population; Johnson, J., Ed.; St. Paul's Church-Yard: London, UK, 1798.

2. Indicators. The World Bank. Available online: http://www.worldbank.org/en/search?q (accessed on 3 June 2020).

3. Overconsumption? Our Use of the World's Natural Resources. Friends of the Earth England, Wales and Northern Ireland. Available online: https://cdn.friendsoftheearth.uk/sites/default/files/downloads/overconsumption. pdf (accessed on 3 June 2020).

4. United Nations, Department of Economic and Social Affairs, Population Division. World Population Prospects 2019: Highlights (ST/ESA/SER.A/423). 2019. Available online: https://population.un.org/wpp/Publications/ Files/WPP2019_Highlights.pdf (accessed on 3 June 2020).

5. Canals, C. The Emergence of the Middle Class: An Emerging-Country Phenomenon. 2019. Available online: https://www.caixabankresearch.com/en/economics-markets/labour-market-demographics/ emergence-middle-class-emerging-country-phenomenon (accessed on 29 September 2020).

6. Fiorino, D.J. The New Environmental Regulation; Mit Press: Cambridge, MA, USA, 2006.

7. Rumelt, R.P.; Schendel, D.; Teece, D.J. Strategic management and economics. Strat. Manag. J. 1991, 12, 5-29. [CrossRef]

8. Nooraie, M. Factors influencing strategic decision-making processes. Int. J. Acad. Res. Bus. Soc. Sci. 2012, 2, 405-429. Available online: https://www.researchgate.net/publication/266228150_Factors_Influencing Strategic_Decision-Making_Processes (accessed on 25 March 2020).

9. ISO 14001 Environmental Management Systems. Available online: http://www. environmentalmanagementsystem.com.au/iso-14001-environmental-management-systems.html (accessed on 25 April 2020).

10. Joshi, A. Corporate Environmental responsibility: A liability or challenge. Electron. J. 2012, 2, 34-36. [CrossRef]

11. Das, T.K. Corporate environmental responsibility excellence. Corp. Soc. Responsib. 2006, 3, 166-174.

12. Dominguez, C.; Varajao, J. Environmental management systems certification: Insights from Portuguese construction companies. Environ. Eng. Manag. J. 2016, 11, 2383-2394. [CrossRef]

13. Giménez, G.; Leal, M.; Casadesús, F.; Valls, J. Using environmental management systems to increase firms' competitiveness. Corp. Soc. Responsib. Environ. Manag. 2003, 10, 101-110. [CrossRef]

14. Herghiligiu, I.V.; Robu, I.-B.; Pislaru, M.; Vilcu, A.; Asandului, A.L.; Avasilcăi, S.; Balan, C. Sustainable environmental management system integration and business performance: A balance assessment approach using fuzzy logic. Sustainability 2019, 11, 5311. [CrossRef]

15. Johnstone, L. A systematic analysis of environmental management systems in SMEs: Possible research directions from a management accounting and control stance. J. Clean. Prod. 2019. [CrossRef]

16. Successful Practices of Environmental Management Systems in Small and Medium-Size Enterprises Commission for Environmental Cooperation. A North American Perspective. Commission for Environmental Cooperation. 2005. Available online: http://www3.cec.org/islandora/en/item/2273-successful-practicesenvironmental-management-systems-in-small-and-medium-size-en.pdf (accessed on 25 July 2020).

17. Iyer, G.V.; Mastorakis, N. Environmental management system for the organization to achieve business excellence. In Proceedings of the 6th WSEAS International Conference on Systems Theory \& Scientific Computation, Elounda, Greece, 8-10 May 2006; Athina, L., Konstantinos, S., Eds.; World Scientific and Engineering Academy and Society: Stevens Point, WI, USA, 2006; pp. 484-495.

18. Khanna, D.R.; Bhutiani, R.; Matta, G. Environmental Management System. J. Comp. Toxicol. Physiol. 2009, $6,10-17$.

19. Dummett, K. Drivers for corporate environmental responsibility (CER). Environ. Dev. Sustain. 2006, 8, 375-389. [CrossRef]

20. Cantele, S.; Zardini, A. What drives small and medium enterprise towards sustainability \& role of interactions between pressures, barriers, and benefits. Corp. Soc. Responsib. Environ. Manag. 2020, 27, 126-136. [CrossRef]

21. Sindhi, S.; Kumar, N. Corporate environmental responsibility-transitional and evolving. Manag. Environ. Qual. 2012, 23, 640-657. [CrossRef]

22. Cosmina, L.; Hoogenberg, B.; Fratostiteanu, C.; Hashmi, H. The Relation between environmental management systems and environmental and financial performance in emerging economies. Sustainability 2020, 12, 5309. [CrossRef] 
23. Henri, J.; Journeault, M. Eco-control: The influence of management control systems on environmental and economic performance. Account. Organ. Soc. 2010, 35, 63-80. [CrossRef]

24. Cater, T.; Prasnikar, J.; Cater, B. Environmental strategies and their motives and results in Slovenian business practice. Econ. Bus. Rev. 2009, 11, 55-74.

25. Gadenne, D.L.; Kennedy, J.; McKeiver, C. An empirical study of environmental awareness and practices in SMEs. J. Bus. Ethics 2009, 84, 45-63. [CrossRef]

26. Serwach, T. Environmental Marketing Strategies in Business and the Environment; Dorozynski, T., Kuna-Marszalek, A., Eds.; Wydawnictwo Uniwersytetu Lodzkiego: Lodz, Poland, 2016; pp. 101-120.

27. Atkinson, G.; Hett, T.; Newcombe, J. Measuring corporate sustainability. J. Environ. Plan. Manag. 2000, 43, 235-252. [CrossRef]

28. Figge, F.; Tobias, H.; Schaltegger, S.; Wagner, M. The Sustainability Balanced Scorecard-Theory and Application of a Tool for Value-Based Sustainability Management. Green. Ind. Netw. 2002, 11, 269-284. Available online: http://www.ecnc.org/uploads/documents/the-sustainably-balanced-scorecard-theory-andapplication-of-a-tool-for-value-based-sustainability-management.pdf (accessed on 5 April 2020).

29. Hart, S.L.; Milstein, M.B. Creating sustainable value. Acad. Manag. Exec. 2003, 17, 56-69. [CrossRef]

30. United Nations Global Compact. Available online: www.unglobalcompact.org/ (accessed on 15 April 2020).

31. Grant, R.M. The resource-based theory of competitive advantage: Implications for strategy formulation. Calif. Manag. Rev. 1999, 33, 3-23. [CrossRef]

32. Pearce, D.; Turner, R. Economics of Natural Resources and the Environment; Harvester Wheatsheaf: London, UK, 1990; pp. 271-287.

33. Perman, R.; Ma, Y.; McGilvray, J.; Common, M. Natural Resource and Environmental Economics, 3rd ed.; Pearson Addison-Wesley: London, UK, 2003; pp. 506-536.

34. Shane, S.; Kolvereid, L. National environment, strategy, and new venture performance: A three country study. J. Small Bus. Manag. 1995, 29, 37-50.

35. Kaplan, R.S.; Norton, D.P. Having trouble with your strategy? Then map it. Harv. Bus. Rev. 2000, 78, 167-176. [PubMed]

36. Deari, F. Investments and financing sources of businesses: Evidence from Pollog region. Econ. Organ. 2010, 7, 245-251.

37. Belderbos, R.; Fukao, K.; Ito, K.; Letterie, W. Global fixed capital investment by multinational firms. The Research Institute of Economy, Trade and Industry. 2013. Available online: http://www.rieti.go.jp/en/ (accessed on 5 April 2020).

38. Fazzari, S.M.; Petersen, B.C. Working capital and fixed investment: New evidence on financing constraints. RAND J. Econ. 1993, 24, 328-342. [CrossRef]

39. Drucker, P.F. The Discipline of Innovation. Harv. Bus. Rev. 2002, 80. Available online: https://www. researchgate.net/publication/11192227_The_Discipline_of_Innovation (accessed on 24 June 2020). [CrossRef]

40. Freeman, C. Technology Policy and Economic Performance: Lessons from Japan; Pinter: London, UK, 1987.

41. Fussler, C.; James, P. Driving Eco-Innovation: A Breakthrough Discipline for Innovation and Sustainability; Pitman Publishing: New York, NY, USA, 1996.

42. Gray, B.; Ariss, S. Politics and change across organization life cycle. Acad. Manag. Rev. 1985, 10, 707-723. [CrossRef]

43. Adizes, I. Corporate Lifecycles: How and Why Corporations Grow and Die and What to Do about It; Prentice Hall: Englewood Cliffs, NJ, USA, 1989.

44. Cooper, R.; Haltiwanger, J.; Power, L. Machine replacement and the business cycle: Lumps and bumps. Am. Econ. Rev. 1999, 89, 921-946. [CrossRef]

45. Lester, D.; Parnell, J.; Carraher, S. Organization life cycle: A five-stage empirical scale. Int. J. Organ. Anal. 2003, 11, 339-354. [CrossRef]

46. Carroll, A. The pyramid of corporate social responsibility: Toward the moral management of organizational stakeholders. Bus. Horiz. 1991, 34, 39-48. [CrossRef]

47. Kasych, A.; Vochozka, M.; Yakovenko, Y. Diagnostic of the stability states of enterprises and the limits of their tolerance. Qual. Access Success 2019, 20, 3-12. 
48. Kasych, A.; Rowland, Z.; Yakovenko, Y. Modern management tools for sustainable development of mining enterprises. In Proceedings of the E3S Web of Conferences, Ukrainian School of Mining Engineering, Berdiansk, Ukraine, 3-7 September 2019; Bondarenko, V., Kovalevska, I., Cawood, F., Hardygora, M., Malova, O., Lysenko, R., Eds.; EDP Sicences: Les Ulis, France, 2019. [CrossRef]

49. Grünig, R.; Kühn, R. Process-Based Strategies Planning; Springer: Berlin/Heidelberg, Germany, 2001.

50. Katsoulakos, T.; Katsoulacos, Y. Strategic management, corporate responsibility and stakeholder management. Corp. Gov. 2007, 7, 355-369. [CrossRef]

51. Kasych, A.; Vochozka, M. The choice of methodological approaches to the estimation of enterprise value in terms of management system goals. Qual. Access Success 2019, 20, 3-9.

52. Environmental Sustainability Index (ESI) (2002). Socioeconomic Data and Applications Center. Available online: https://sedac.ciesin.columbia.edu/es/esi/ESI2002_21MAR02a.pdf. (accessed on 17 June 2020).

53. Environmental \& Socially Responsible Index. S \& P Dow Jones Indices. Available online: https://www. spglobal.com/spdji/en/indices/equity/sp-500-environmental-socially-responsible-index/\#overview (accessed on 24 June 2020).

54. Measuring Sustainable Development. Integrated Economic, Environmental and Social Frameworks. 2004. Available online: http://www.oecd.org/site/worldforum/33703829.pdf (accessed on 2 June 2020).

55. Mondéjar-Jiménez, J.; Mondéjar-Jiménez, J.A.; Vargas-Vargas, M.; Gázquez-Abad, J.C. Personal attitudes in environmental protection. Int. J. Environ. Res. 2012, 6, 1039-1044. [CrossRef]

56. Senetra, A.; Pawlewicz, K.; Pawlewicz, A. The dynamics of changes and spatial differences in the synthetic indicator for evaluating environmental performance in Poland: Current State. Int. J. Environ. Res. Public Health 2019, 16, 4490. [CrossRef] [PubMed]

57. Mondéjar-Jiménez, J.; Vargas-Vargas, M.; Mondéjar-Jiménez, J.-A. Measuring environmental evolution using synthetic indicators. Environ. Eng. Manag. J. 2010, 9, 1145-1149. [CrossRef]

58. Gilal, F.G.; Gilal, N.G.; Channa, N.A.; Gilal, R.G.; Tunio, M.N. Towards an integrated model for the transference of environmental responsibility. Bus. Strategy Environ. 2020, 29, 2614-2623. [CrossRef]

59. Forcadell, F.J.; Úbeda, F.; Aracil, E. Effects of environmental corporate social responsibility on innovativeness of Spanish industrial SMEs. Technol. Forecast. Soc. Chang. 2021, 162. [CrossRef]

60. García-Pozo, A.; Mondéjar-Jiménez, J.; Sánchez-Ollero, J.L. Internet's user perception of corporate social responsibility in hotel services. Sustainability 2019, 11, 2916. [CrossRef]

61. Eco-efficiency Indicators: Measuring Resource-Use Efficiency and the Impact of Economic Activities on the Environment. United Nations Publication/ESCAP. 2002. Available online: https://sustainabledevelopment. un.org/content/documents/785eco.pdf (accessed on 12 June 2020).

62. Toshiba Group Environmental Report 2019. Available online: https://www.toshiba.co.jp/sustainability/en/ report/download.htm (accessed on 14 June 2020).

63. Official Site of Volkswagen Group. Available online: www.volkswagenag.com/vwag/vwcorp/content/en/ homepage.html (accessed on 4 June 2020).

64. Official Site of General Motors. Available online: http://www.gm.com (accessed on 18 June 2020).

65. Official Site of Ford Motor. Available online: http://www.ford.com (accessed on 12 June 2020).

66. Official Site of Nissan. Available online: http://www.nissan-global.com (accessed on 4 June 2020).

67. Official Site of Toyota. Available online: http://www.toyota.com (accessed on 14 June 2020).

Publisher's Note: MDPI stays neutral with regard to jurisdictional claims in published maps and institutional affiliations.

(C) 2020 by the authors. Licensee MDPI, Basel, Switzerland. This article is an open access article distributed under the terms and conditions of the Creative Commons Attribution (CC BY) license (http://creativecommons.org/licenses/by/4.0/). 